Research Article

\title{
Synthesis, DNA-Binding, Anticancer Evaluation, and Molecular Docking Studies of Bishomoleptic and Trisheteroleptic Ru-Diimine Complexes Bearing 2-(2-Pyridyl)-quinoxaline
}

\author{
Sofia Balou ${ }^{D}$, ${ }^{1}$ Athanasios Zarkadoulas $\mathbb{D D}^{1}{ }^{1}$ Maria Koukouvitaki, ${ }^{1}$ Luciano Marchiò ${ }^{(D)},{ }^{2}$ \\ Eleni K. Efthimiadou $\left(\mathbb{D},{ }^{1}\right.$ and Christiana A. Mitsopoulou $(\mathbb{1})^{1}$ \\ ${ }^{1}$ Inorganic Chemistry Laboratory, Chemistry Department, National and Kapodistrian University of Athens, Panepistimiopolis, \\ Zografou 157 71, Greece \\ ${ }^{2}$ Dipartimento di Scienze Chimiche, della Vita e della Sostenibilità Ambientale, Università degli Studi Parma, \\ Parco Area delle Scienze 17A, I43124 Parma, Italy
}

Correspondence should be addressed to Christiana A. Mitsopoulou; cmitsop@chem.uoa.gr

Received 3 February 2021; Accepted 21 April 2021; Published 13 May 2021

Academic Editor: Domenico Osella

Copyright (C) 2021 Sofia Balou et al. This is an open access article distributed under the Creative Commons Attribution License, which permits unrestricted use, distribution, and reproduction in any medium, provided the original work is properly cited.

Herein, we report the synthesis and characterization of a bishomoleptic and a trisheteroleptic ruthenium (II) polypyridyl complex, namely, $\left[\mathrm{Ru}(\mathrm{bpy}) 2\left(2,2^{\prime}\right.\right.$-pq)](PF6)2 (1) and [Ru(bpy) (phen) (2, 2'-pq)](PF6)2 (2), respectively, where bpy $=2,2^{\prime}$-bipyridine, phen $=1,10$-phenanthroline, and $2,2^{\prime}-\mathrm{pq}=2$ - $\left(2^{\prime}\right.$-pyridyl $)$-quinoxaline. The complexes were characterized by elemental analysis, TGA, ${ }^{1} \mathrm{H}-\mathrm{NMR}$, FT-IR, UV-Vis, emission spectroscopy, and electrochemistry. Their structures were confirmed by single-crystal $\mathrm{X}$-ray diffraction analysis. Complexes 1 and 2 were crystalized in orthorhombic, Pbca, and monoclinic, P21/n systems, respectively. Various spectroscopic techniques were employed to investigate the interaction of both complexes with calf thymus DNA (CT-DNA). The experimental data were confirmed by molecular docking studies, employing two different DNA sequences. Both complexes, 1 and 2, bind with DNA via a minor groove mode of binding. MTT experiments revealed that both complexes induce apoptosis of MCF-7 (breast cancer) cells in low concentrations. Confocal microscopy indicated that 2 localizes in the nucleus and internalizes more efficiently in MCF-7 than in HEK-293.

\section{Introduction}

Ruthenium diimine complexes have long attracted interest due to their various applications in catalysis $[1,2]$ and in metal-based drugs [3]. More specifically, ruthenium diimine complexes exhibit telomerase and topoisomerase inhibition $[4,5]$ as well as protease activity [6]. They can induce apoptosis in cancer cells in various stages of the replication cell cycle via intercalation or after photoexcitation, leading to applications in photodynamic therapy $[7,8]$.

Focusing on the ligand framework, peripheral functionalization of diimines has led to the development of multipotent metal-based drugs containing second and third row transition metals bearing dipyridophenazine (dppz) [9], 1,10-phenanthroline-5,6-dione $[10,11]$, or quinoxaline ligands [12-14]. More specifically, 2, 2'-pq proved a versatile ligand that can bind to a plethora of transition metals [15]. The quinoxaline moiety is found in many molecules of medicinal interest that exhibit antibacterial, antiviral, antifungal, anthelmintic, and anticancer properties [16, 17].

When coordinated to metal ions, the resulting complexes have interesting bioinorganic applications. For example, $\left[\operatorname{ReOCl}_{3}\left(2,2^{\prime}\right.\right.$-pq)] can efficiently cleave plasmid pBR 322DNA upon irradiation by generating singlet oxygen and hydroxyl radicals [18]. Furthermore, incorporation of $2,2^{\prime}$ $\mathrm{pq}$ in Pt-diamine complexes [19] and study against murine leukemia results in $\mathrm{IC}_{50}$ values in the range of $\sim 40 \mu \mathrm{M}$. Square planar and octahedral $\mathrm{Rh}(\mathrm{I})$ and $\mathrm{Rh}(\mathrm{II})$ complexes comprise 2, $2^{\prime}$-pq as a ligand exhibit activity against the platelet-activating factor (PAF) [20], while organometallic 
$\mathrm{Ru}(\mathrm{II})$ complexes with arene ligands and 2, 2'-pq [21] bind to oligonucleotides and exhibit cytotoxic properties with IC $_{50}<1 \mu \mathrm{M}$. Ruthenium complexes bearing $2,2^{\prime}$-pq ligand have also been reported [22], with both $\Delta^{-}$and $\Lambda^{--}$ enantiomers of $\left[\mathrm{Ru}(\mathrm{bpy})_{2}\left(2,2^{\prime} \text {-pq }\right)\right]^{2+}$ binding to oligonucleotide duplex d(CGCGAATTCGCG) 2 [23].

Trisheteroleptic diimine Ru complexes for bioinorganic chemistry applications are quite scarce in the literature, one example being the $\left[\mathrm{Ru} \text { (bpy) (dppn) }\left(\mathrm{CH}_{3} \mathrm{CN}\right)_{2}\right]^{2+}$ reported by Albani et al. [24], which exhibits a dual action, both ${ }^{1} \mathrm{O}_{2}$ generation and ligand exchange after irradiation. In another instance, a library of $28 \mathrm{Ru}$ (II) trisheteroleptic diimine complexes was prepared using solid-phase synthesis to yield $\left[\mathrm{Ru}\left(\right.\right.$ phen- $\left.-\mathrm{Me}_{2}\right)\left(\mathrm{dppz}-\mathrm{Me}_{2}\right)$ (phen- $\left.\left.\mathrm{CONH}_{2}\right)\right]^{2+}$ as a $500-$ time more potent inhibitor against acetylcholinesterase than homoleptic [ $\left.\mathrm{Ru}(\mathrm{phen})_{3}\right] \mathrm{Cl}_{2}$ [25]. Moreover, Bhat et al. [26] recently reported trisheteroleptic $\mathrm{Ru}$-complexes that exhibit the "molecular light switch" effect and are toxic against HeLa and HL-60 cell lines, while cellular uptake is localized in the cell nucleus. These reports show the high potential of $\mathrm{Ru}-$ trisheteroleptic complexes in the design of multimodal metallotherapeutic agents [27].

Inspired by the proven affinity of $2,2^{\prime}$-pq-containing metal complexes for DNA and the diversity of opportunities opening from incorporating a trisheteroleptic ligand manifold around $\mathrm{Ru}(\mathrm{II})$, in this study, we report the preparation and characterization of the trisheteroleptic $[\mathrm{Ru}(\mathrm{bpy})$ (phen) $\left.\left(2,2^{\prime}-\mathrm{pq}\right)\right]\left(\mathrm{PF}_{6}\right)_{2}$ complex along with its $\left[\mathrm{Ru}(\mathrm{bpy})_{2}\left(2,2^{\prime}-\right.\right.$ $\mathrm{pq})]\left(\mathrm{PF}_{6}\right)_{2}$ counterpart. The latter was studied because although its fully structural characterization has not to be presented before, its binding mode to DNA has been reported; thus, it can be a good comparison for our results. As a consequence, both complexes (Scheme 1) have been structurally characterized, and the interaction of the trisheteroleptic complex with CT-DNA is reported. Moreover, both complexes were tested against MCF-7 and HEK-293 cancer cells, while molecular docking analysis has been performed to obtain detailed information on the binding mode of complexes 1 and 2 with CT-DNA.

\section{Experimental}

\subsection{Materials and Methods}

2.1.1. General Considerations. Solvents and reagents were used as received from Aldrich, Fisher, and Merck. $\mathrm{CDCl}_{3}$ was further purified by distillation over $\mathrm{K}_{2} \mathrm{CO}_{3}$ and was stored over $4 \mathrm{~A}$ molecular sieves in dark. Elemental analyses were obtained by a LECO-183 CHNS analyzer. IR spectra were conducted on a $2.0 \mathrm{~cm}^{-1}$ resolution Shimadzu IR Affinity-1 spectrometer using $\mathrm{KBr}$ pellets. Varian Unity Plus instrument $(300 \mathrm{MHz})$ was used for obtaining NMR spectra, the correction of which was carried out by implementing the solvent peak as an internal standard. Both Hitachi U-2000 and Varian Cary 3E spectrophotometers were used for recording the UV-Vis spectra. The path length of the used quartz cuvettes was $1.0 \mathrm{~cm} .2-2^{\prime}$-pyridyl-quinoxaline $\left(2,2^{\prime}\right.$ pq) [28], cis-[ $\left.\mathrm{Ru}(\mathrm{bpy})_{2} \mathrm{Cl}_{2}\right]$ [29], and cis-[Ru(DMSO) $\left.{ }_{4} \mathrm{Cl}_{2}\right]$ [30] were prepared as mentioned in the literature, and all

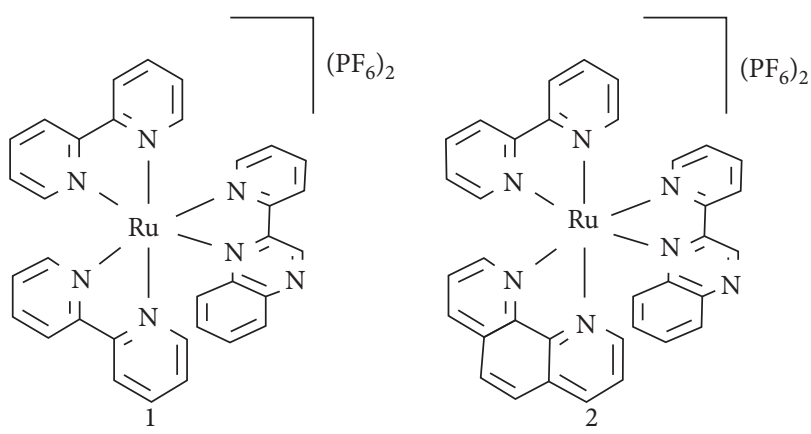

Scheme 1: Chemical structures of complexes under study in this work (complexes 1 and 2).

analytical data agree with those reported. HRMS spectra were recorded using a Q-TOF mass spectrometer (Maxis Impact, Bruker Daltonics, Bremen, Germany). TGA was performed with a TGA/DCS1 Mettler Toledo analyzer. More details on experimental procedures can be found in the supporting information.

2.1.2. Electrochemistry. All electrochemical experiments were conducted on AFCBP1 Pine Instrument Company potentiostat. A three-electrode cell was used for obtaining cyclic voltammograms. The used electrodes were a glassy carbon working one, a platinum wire counter electrode, and a reference electrode, namely, $\mathrm{Ag} / \mathrm{AgCl}(\mathrm{KCl} 3 \mathrm{M})$. The latter was replaced in some measurements by an $\mathrm{Ag}$ wire pseudoreference electrode. Before each measurement, the working electrode was refined with alumina paste $(1 \mu \mathrm{m})$ on a polishing cloth. Before each measurement, the solution was purged with argon gas for $10 \mathrm{~min}$, and ferrocene was used as an internal standard. All voltammograms were recorded at a $100 \mathrm{mV} / \mathrm{s}$ scan rate unless otherwise noted.

2.1.3. X-ray Structure Determination. Table 1 summarizes the data collection and structure refinement for 1 and 2 . $\mathrm{X}$-ray structure determination was performed on suitable single red crystals of 1 and 2 which were grown by layering their concentrated dichloromethane solution with $n$-hexane. Single crystal data were collected with a Bruker Smart Breeze area detector diffractometer (Mo $\mathrm{Ka}$ radiation, $\lambda=0.71073 \AA$ ). The intensity data were integrated from several series of exposure frames ( 0.3 width) covering the sphere of reciprocal space [31]. The structure was solved SHELXT [32] and refined on F2 with full-matrix least squares (SHELXL-2014) [33], using Olex2 software package [34]. Graphical material was prepared with the Mercury 3.10 program [35]. CCDC deposition number is 20522122052213.

\subsection{Synthesis of $R u$ Complexes}

2.2.1. Synthesis of $\left[R u(b p y)_{2}\left(2,2^{\prime}-p q\right)\right]\left(P F_{6}\right)_{2}$ (1). $100 \mathrm{mg}$ $(0.206 \mathrm{mmol})$ of cis- $\left[\mathrm{Ru}(\text { bpy })_{2} \mathrm{Cl}_{2}\right]$ and $51.2 \mathrm{mg}$ (1.2 eq.) of 2 , $2^{\prime}$-pq were dissolved in an $8: 2$ ethanol-water $20 \mathrm{~mL}$ mixture, 
TABLe 1: Crystal data and structure refinement for 1 and 2.

\begin{tabular}{|c|c|c|}
\hline Identification code & 1 & 2 \\
\hline Empirical formula & $\mathrm{C}_{34} \mathrm{H}_{27} \mathrm{Cl}_{2} \mathrm{~F}_{12} \mathrm{~N}_{7} \mathrm{O}_{0.5} \mathrm{P}_{2} \mathrm{Ru}$ & $\mathrm{C}_{35.7} \mathrm{H}_{26.4} \mathrm{Cl}_{1.4} \mathrm{~F}_{12} \mathrm{~N}_{7} \mathrm{O}_{0.3} \mathrm{P}_{2} \mathrm{Ru}$ \\
\hline Formula weight & 1003.54 & 998.88 \\
\hline Temperature & 293(2) K & 293(2) K \\
\hline Wavelength & $0.71073 \mathrm{~A}$ & $0.71073 \mathrm{~A}$ \\
\hline \multirow[t]{2}{*}{ Crystal system, space group } & Orthorhombic, Pbca & Monoclinic, $\mathrm{P} 2{ }_{1} / n$ \\
\hline & $a=28.44(1) \mathrm{A}$ alpha $=90 \mathrm{deg}$ & $a=11.026(1)$ A alpha $=90 \mathrm{deg}$ \\
\hline \multirow[t]{2}{*}{ Unit cell dimensions } & $b=19.332(9)$ A beta $=90 \mathrm{deg}$. & $b=14.398(1)$ A beta $=90.284(1) \mathrm{deg}$. \\
\hline & $c=14.369(7)$ A gamma $=90 \mathrm{deg}$. & $c=24.972(2)$ A gamma $=90$ deg. \\
\hline Volume & $7900(6) \mathrm{A}^{3}$ & $3964.3(6) \mathrm{A}^{3}$ \\
\hline Z, calculated density & $8,1.689 \mathrm{Mg} / \mathrm{m}^{3}$ & $4,1.674 \mathrm{Mg} / \mathrm{m}^{3}$ \\
\hline Absorption coefficient & $0.708 \mathrm{~mm}^{-1}$ & $0.666 \mathrm{~mm}^{-1}$ \\
\hline $\mathrm{F}(000)$ & 4008 & 1991 \\
\hline Crystal size & $0.31 \times 0.24 \times 0.12 \mathrm{~mm}$ & $0.32 \times 0.17 \times 0.15 \mathrm{~mm}$ \\
\hline Theta range for data collection & $1.78-24.75 \mathrm{deg}$ & $1.63-25.16 \mathrm{deg}$ \\
\hline Limiting indices & $-33 \leq h \leq 33,-22 \leq k \leq 22,-16 \leq l \leq 16$ & $13 \leq h \leq 13,-17 \leq k \leq 17,-29 \leq l \leq 29$ \\
\hline Reflections collected/unique & $56369 / 6722(\mathrm{R}(\mathrm{int})=0.0820)$ & $42163 / 7067(\mathrm{R}($ int $)=0.0732)$ \\
\hline Data/restraints/parameters & $6722 / 5 / 569$ & $7067 / 248 / 664$ \\
\hline Goodness-of-fit on $\mathrm{F}^{2}$ & 1.032 & 1.078 \\
\hline Final $R$ indices $(\mathrm{I}>2 \operatorname{sigma}(\mathrm{I}))$ & $R_{1}=0.0657, \mathrm{wR}_{2}=0.1604$ & $R_{1}=0.0655, \mathrm{wR}_{2}=0.1455$ \\
\hline Largest diff. peak and hole & 2.22 and -1.01 e. $\mathrm{A}^{-3}$ & 0.59 and -0.53 e. $\mathrm{A}^{-3}$ \\
\hline
\end{tabular}

and the solution was refluxed overnight. The solvents were removed in a rotary evaporator, and a saturated solution of $\mathrm{KPF}_{6}$ in water was added $(15 \mathrm{~mL})$, which resulted in the formation of a red precipitate. The mixture was filtered in a sintered funnel, washed with water and ether, and air-dried. The resulting solid was dissolved in a minimum amount of $\mathrm{MeCN}$ and subjected to column chromatography (neutral alumina, MeCN solvent). The orange band eluting first was isolated, concentrated, and addition of ether afforded $160 \mathrm{mg}$ of a red solid. Yield: $85 \%$. Anal. found (calc.) for $\mathrm{C}_{33} \mathrm{H}_{25} \mathrm{~F}_{12} \mathrm{~N}_{7} \mathrm{P}_{2} \mathrm{Ru}$ : C, 43.10 (43.53); H, 2.81 (2.77); and $\mathrm{N}$, 10.80 (10.77). ${ }^{1} \mathrm{H}-\mathrm{NMR}$ (acetone- $\left.\mathrm{d}_{6}, \mathrm{ppm}\right): 10.10$ (s, 1H, 2, $2^{\prime}$-pq), 9.26 (d, 1H, 2, 2' -pq), 8.90 (d, 2H), 8.76 (d, 1H, 2, 2' pq), 8.64 (d, 1H, 2, 2' -pq), 8.34-8.09 (m, 9H), $7.96(\mathrm{~d}, 1 \mathrm{H})$, $7.89(\mathrm{~m}, 1 \mathrm{H}), 7.79(\mathrm{~d}, 1 \mathrm{H}), 7.66(\mathrm{~m}, 2 \mathrm{H})$, and 7.57-7.47 $(\mathrm{m}$, 5H). IR $\left(\mathrm{KBr}, \mathrm{cm}^{-1}\right): 842\left(\mathrm{PF}_{6}^{-}\right)$and $761\left(\mathrm{PF}_{6}^{-}\right)$. HRMS-ESI, positive in $\mathrm{MeOH}$, and $\mathrm{m} / \mathrm{z}: 310.5596 / 2$ (calc., 310.56).

2.2.2. Synthesis of $[R u(b p y) \text { (phen) (2, 2'-pq)](PF })_{2}$ (2). $33 \mathrm{mg}(0.0649 \mathrm{mmol})$ cis- $\left[\mathrm{Ru}(\mathrm{bpy})\right.$ (phen) $\left.\mathrm{Cl}_{2}\right]$ (details in SI ) and $16.14 \mathrm{mg}$ (1.2 eq) of $2,2^{\prime}$-pq were dissolved in an $8: 2$ $10 \mathrm{~mL}$ ethanol-water mixture, and the solution was refluxed overnight. The solvents were removed in a rotary evaporator, and a saturated solution of $\mathrm{KPF}_{6}$ in water was added $(15 \mathrm{~mL})$, which resulted in the formation of a brown-orange precipitate. The mixture was filtered in a sintered funnel, washed with water and ether, and air-dried. The resulting solid was dissolved in a minimum amount of $\mathrm{MeCN}$ and subjected to column chromatography (neutral alumina, MeCN solvent). The orange band eluting first was isolated, concentrated, and addition of ether afforded $51 \mathrm{mg}$ of a redorange solid. Yield: 84\%. Anal. found (calc.) for $\mathrm{C}_{35} \mathrm{H}_{25} \mathrm{~F}_{12} \mathrm{~N}_{7} \mathrm{P}_{2} \mathrm{Ru}$ : C, 44.64 (44.98); $\mathrm{H}, 2.81$ (2.70); and $\mathrm{N}$, 10.56 (10.49). ${ }^{1} \mathrm{H}-\mathrm{NMR}$ (DMSO-d 6 , ppm): 10.19 (s, 1H, 2, 2' pq), $9.30\left(\mathrm{~d}, 1 \mathrm{H}, 2,2^{\prime}-\mathrm{pq}\right), 8.85-8.74(\mathrm{~m}, 6 \mathrm{H}), 8.44(\mathrm{t}, 2 \mathrm{H})$, $8.26(\mathrm{~m}, 2 \mathrm{H}), 8.13-7.97(\mathrm{~m}, 2 \mathrm{H}), 7.87-7.69(\mathrm{~m}, 4 \mathrm{H})$, 7.52-7.30 (m, 6H), and $7.16(\mathrm{~m}, 1 \mathrm{H})$. IR $\left(\mathrm{KBr}, \mathrm{cm}^{-1}\right): 840$ $\left(\mathrm{PF}_{6}^{-}\right)$and $770\left(\mathrm{PF}_{6}^{-}\right)$. HRMS-ESI, positive in $\mathrm{MeOH}$, and $\mathrm{m} / \mathrm{z}: 322.5589 / 2$ (calc.: 322.561 ).

2.3. DNA-Binding Studies of Complex 2. All experiments involving DNA interactions with complex 2 were carried out in Tris- $\mathrm{HCl}$ buffer with $\mathrm{pH}=7.0$ which was prepared by dissolving $0.394 \mathrm{~g}(2.5 \mathrm{mmol})$ of Tris(hydroxymethyl)aminomethane hydrochloride (Tris- $\mathrm{HCl})$ and $1.461 \mathrm{~g}(25 \mathrm{mmol})$ of NaCl in $500 \mathrm{~mL}$ of Milli-Q water. A detailed description of the methodology is given in SI under the DNA binding studies including circular dichroism (CD) measurements, absorption titration, viscosity measurements, and fluorescence emission spectroscopy.

2.3.1. In Vitro Cytotoxicity Studies and Confocal Microscopy. The MTT assay was used for testing the growth inhibition of MCF-7 and HEK-293 cells for compounds 1 and 2 and cisplatin [36]. Confocal laser microscopy was used for studying the cellular uptake of each compound. A detailed description of the methods is also provided in SI.

2.3.2. Molecular Docking Study. Docking studies were carried out using MGL tools 1.5.4 with AutoGrid4 and AutoDock4 to perform blind docking calculations between both ruthenium (II) complexes and DNA sequence. A full description is provided in SI together with the output files.

\section{Results and Discussion}

3.1. Synthesis. The preparation of desired complexes was achieved as shown in Scheme 2. To achieve the preparation of trisheteroleptic ruthenium complexes, several ways have been proposed in the literature [37-39], mainly by using carbonyl $\mathrm{Ru}$ complexes or photochemical processes. 
However, we found that the most convenient and reliable method to obtain the trisheteroleptic Ru complex was by stepwise substitution of labile ligands, with each intermediate easily isolable and characterized. Thus, initially, two DMSO molecules were substituted by one bpy molecule in the cis- $\left[\mathrm{Ru}(\mathrm{DMSO})_{4} \mathrm{Cl}_{2}\right]$ precursor, as mentioned in the literature [40]. The use of $\mathrm{CHCl}_{3}$ resulted in low yields and insoluble products; therefore, refluxing toluene was chosen as a solvent, instead [41]. Reaction of the cis-[Ru(bpy) $(\mathrm{DMSO})_{2} \mathrm{Cl}_{2}$ ] with one eq. phen in refluxing DMF in the presence of 10 eq. $\mathrm{LiCl}$ resulted in the formation of the heteroleptic cis-[Ru(bpy) (phen) $\left.\mathrm{Cl}_{2}\right]$ complex. In turn, this intermediate reacted with one eq. of $2,2^{\prime}-\mathrm{pq}$ ligand in refluxing $\mathrm{EtOH}$-water mixture which, after chloride- $\mathrm{PF}_{6}{ }^{-}$ exchange, afforded the desired trisheteroleptic complex 2.

Both complexes 1 and 2 were thermally stable up to $300^{\circ} \mathrm{C}$, as evidenced by their thermograms (see SI for detailed discussion, Figure S1 and Table S1), and their purity was identified by elemental analysis. The high-resolution mass spectra for both complexes, in the positive mode in methanol, and their corresponding isotope distribution patterns are in accordance with the proposed structure (Scheme 1).

3.2. Electronic Absorption and Emission Spectroscopy. UV-Vis spectra of complexes 1 and 2 measured in acetonitrile display typical MLCT transitions in the visible region of the spectrum. More specifically, both complexes display absorption maxima at $507 \mathrm{~nm}$ and $428 \mathrm{~nm}$ with molar absorptivity values of $5000-10000 \mathrm{M}^{-1} \cdot \mathrm{cm}^{-1}$, respectively, both assigned as transitions to singlet MLCT excited states $\left(\mathrm{Ru}^{\mathrm{II}} \longrightarrow \pi^{*}\right.$ diimine $)[42]$. These bands are separated by $79 \mathrm{~nm}$ due to the different energy of diimine orbitals that leads to two different transitions. However, the difference in energy of the orbitals of the three distinct diimines in the trisheteroleptic complex 2 is not large enough to lead to the appearance of three bands [39]. The long tail after $500 \mathrm{~nm}$ in both spectra indicates a transition to the spin-forbidden ${ }^{3}$ MLCT state, as reported for similar complexes [43].

Both complexes display a single broad emission band when excited at $500 \mathrm{~nm}$ in acetonitrile solution, with an emission wavelength of $750 \mathrm{~nm}$. This emission arises from the lowest-lying ${ }^{3}$ MLCT state that is formed via intersystem crossing from a ${ }^{1}$ MLCT after absorption [42, 44]. Normalized absorption and emission spectra for complexes 1 and 2 are shown in Figure 1 with results summarized in Table 2.

3.3. Electrochemical Data. Cyclic voltammograms of 1 and 2 in $\mathrm{MeCN}$ are shown in Figure 2, and $E_{1 / 2}$ values are given in Table 3. Both complexes display a set of three reversible reductions and one reversible oxidation. The reductions are ligand-based while the oxidation has been designated as $\mathrm{Ru}^{\mathrm{II} / \mathrm{III}}$ oxidation $[42,45]$.

$$
[\operatorname{RuII}(\mathrm{L} 1)(\mathrm{L} 2)(\mathrm{L} 3)]^{2+}+\mathrm{e}^{-} \longrightarrow\left[\operatorname{RuII}\left(\mathrm{L}^{--}\right)(\mathrm{L} 2)(\mathrm{L} 3)\right]^{+} .
$$

Replacing a bpy ligand of 1 with a phen ligand yields complex 2, with the reduction potentials being slightly affected. More specifically, the first reduction for complex 1 is located at $-1.023 \mathrm{~V}$ vs $\mathrm{Fc}^{+/ 0}$, while for complex 2 , it occurs at $-0.889 \mathrm{~V}$ vs. $\mathrm{Fc}^{+/ 0}$. This trend is continued for the next reductions, with the reductions of complex 2 occurring at $\sim 140 \mathrm{mV}$ less-negative values. This can be explained in terms of the $\pi^{*}$-accepting ability of the diimines. Since phen has lower lying $\pi^{*}$-orbitals than bpy due to the increased delocalization over one more fused aromatic ring, complex 2 can be more easily reduced than 1 . The reversible oxidation lies at $1.190 \mathrm{~V}$ and at $1.343 \mathrm{~V}$ vs $\mathrm{Fc}^{+/ 0}$ for 1 and 2 , respectively. Increased back donation from $\mathrm{Ru}^{\mathrm{II}}$ orbitals to the $\pi^{*}$ orbitals of diimine stabilizes the +2 oxidation state resulting in more positive potential required to oxidize the trisheteroleptic complex.

3.4. Crystal Structure Determination. We isolated single crystals suitable for X-ray structure determination for complexes 1 and 2. The molecular structures are shown in Figure 3, and selected bond distances are summarized in Table 4. In both complexes, the metal adopts a distorted octahedral coordination environment, according to the presence of the three bidentate ligands forming five-membered chelate rings with bite angles of approximately $78^{\circ}$. Furthermore, in both complexes, the metal- $\mathrm{N}_{\text {quinoxaline }}$ bond length is elongated with respect to the metal- $\mathrm{N}_{\text {pyridyl }}$ bond length, and this difference can be explained in terms of the less $\sigma$-donating ability of the quinoxaline $\mathrm{N}$-atom with respect to the $\mathrm{N}_{\text {pyridyl }}$ moiety. In support of this observation, it is instructive to compare the crystal structures of several latetransition metal complexes that contain the 2, $2^{\prime}$-pq ligand, which were reported by us, in particular, complexes with Mo [46], $\operatorname{Re}[18,47,48]$, and $\mathrm{W}[49,50]$. In all cases, the same trend for the metal- $\mathrm{N}_{\text {quinoxaline }}$ and metal- $\mathrm{N}_{\text {pyridyl }}$ bond lengths, found in 1 and 2, is also found for these complexes (Table 5). In addition and by inspecting in more detail the structural information between 1 and 2, a shorter metal$\mathrm{N}_{\text {quinoxaline }}$ bond length in $2(2.097 \AA)$ when compared to 1 $(2.119 \AA)$ can be evidenced, pointing to a possible increase in the metal- $\mathrm{N}_{\text {quinoxaline }}$ bond strength in 2 . This geometric observation is in line with electrochemical measurements discussed earlier, which would imply a more pronounced back-donation of the quinoxaline moiety in complex 2 .

\subsection{DNA-Binding Studies}

3.5.1. Circular Dichroism Experiments. Circular dichroism studies enabled the monitoring of the extent of conformation of DNA in the presence of increasing concentrations of complex 2, since it is well known that DNA CD spectrum alters in the presence of a binding molecule. This is either due to the pairing of DNA and ligand transitions or due to modifications in the DNA base coupling followed by changes in the geometry. As CD spectra reveal (Figure 4), addition of complex 2 changes the intensity of both spectrum bands of CT-DNA's B-form. In the presence of complex 2, the positive band at $280 \mathrm{~nm}$ decreases 


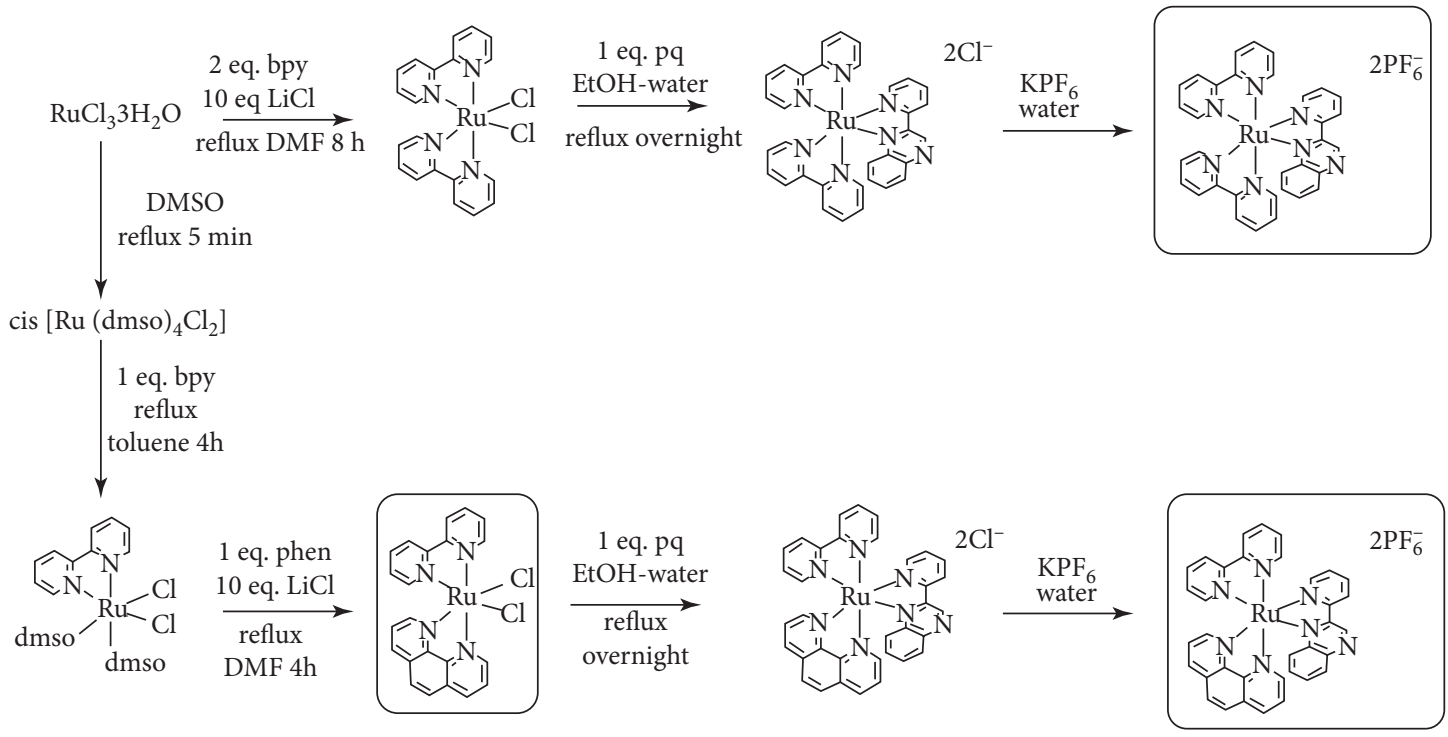

Scheme 2: Preparation routes for complexes 1 and 2.

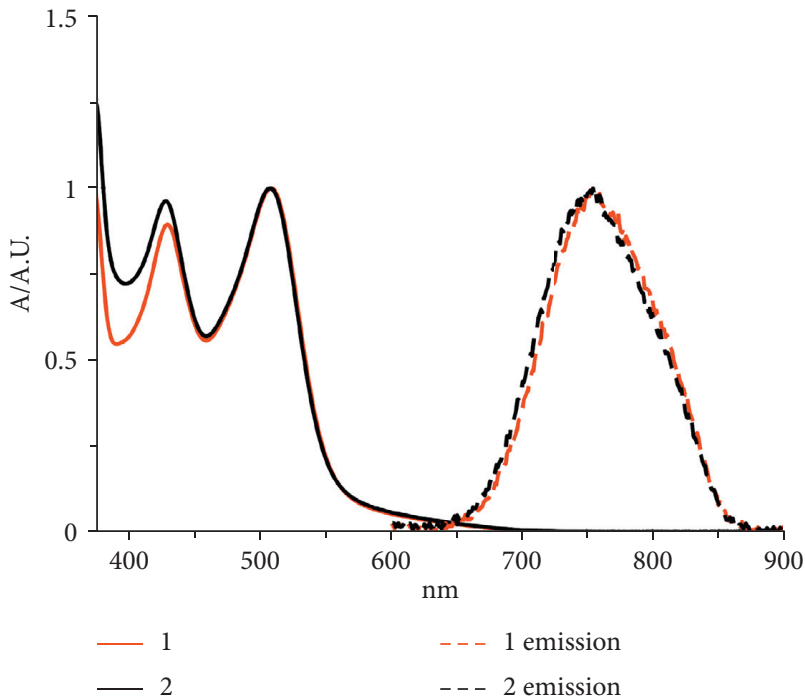

Figure 1: Normalized UV-Vis and emission spectra of complexes 1 (red trace) and 2 (blue trace) in acetonitrile.

TABle 2: Spectroscopic properties for complexes 1 and 2.

\begin{tabular}{lccc}
\hline Compound & $\lambda_{\text {max. }}(\mathrm{nm})^{\mathrm{a}}$ & $\varepsilon\left(\mathrm{M}^{-1} \mathrm{~cm}^{-1}\right)$ & $\lambda \mathrm{em}(\mathrm{nm})^{\mathrm{b}}$ \\
\hline 1 & 508 & 10800 & 755 \\
& 429 & 9730 & \\
2 & 507 & 10100 & 755 \\
& 428 & 9700 & \\
\hline
\end{tabular}

${ }^{\mathrm{a}}$ Measured in $\mathrm{MeCN}$ in a $1.0 \mathrm{~cm}$ cuvette. ${ }^{\mathrm{b}}$ Measured in $\mathrm{MeCN}$ in a $1.0 \mathrm{~cm}$ cuvette, excitation at $500 \mathrm{~nm}$.

significantly in intensity, which suggests nonclassical intercalation [53]. Additionally, the negative peak at $246 \mathrm{~nm}$ increases, and a slight blue shift is concurrently noticed. Thus, the raise of negative band leads to gradual unfolding of DNA. Furthermore, the decrease observed at the maximum positive peak indicates a more compact structure $[54,55]$.

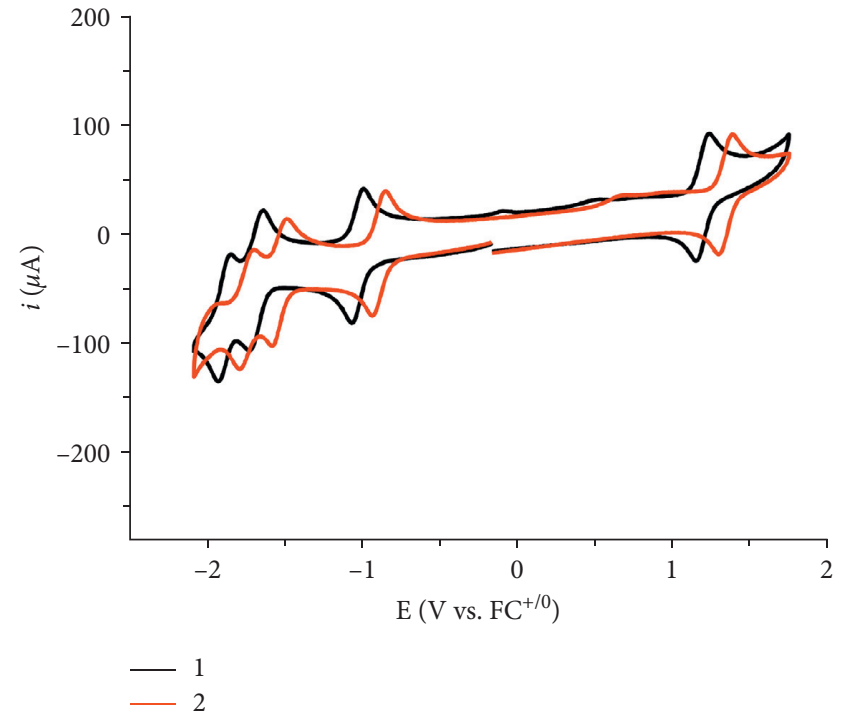

Figure 2: Cyclic voltammograms for complexes 1 (black trace) and 2 (red trace) in acetonitrile.

TABLE 3: $E_{1 / 2}$ values for complexes 1 and 2 .

\begin{tabular}{lcccc}
\hline Compound & \multicolumn{4}{c}{$E_{1 / 2}{ }^{\mathrm{a}}$} \\
\hline 1 & 1.190 & -1.023 & -1.678 & -1.890 \\
2 & 1.343 & -0.889 & -1.529 & -1.743 \\
\hline${ }^{\mathrm{a}}$ Values in volts, measured in an $\mathrm{MeCN}$ solution with a glassy carbon \\
electrode, an Ag wire pseudoreference electrode vs. the $\mathrm{Fc}^{+/ 0}$ redox couple
\end{tabular}
with $\mathrm{NBu}_{4} \mathrm{PF}_{6}$ supporting electrolyte, $100 \mathrm{mV} / \mathrm{s}$ scan rate.

The consequent changes in the CD spectra indicate changes in base stacking and unwinding of the helix conformation of CT-DNA. These types of alterations in the CD signals can be assigned to modifications on the secondary structure of DNA and offer additional evidence that complex 2 binds at the groove of the DNA. 

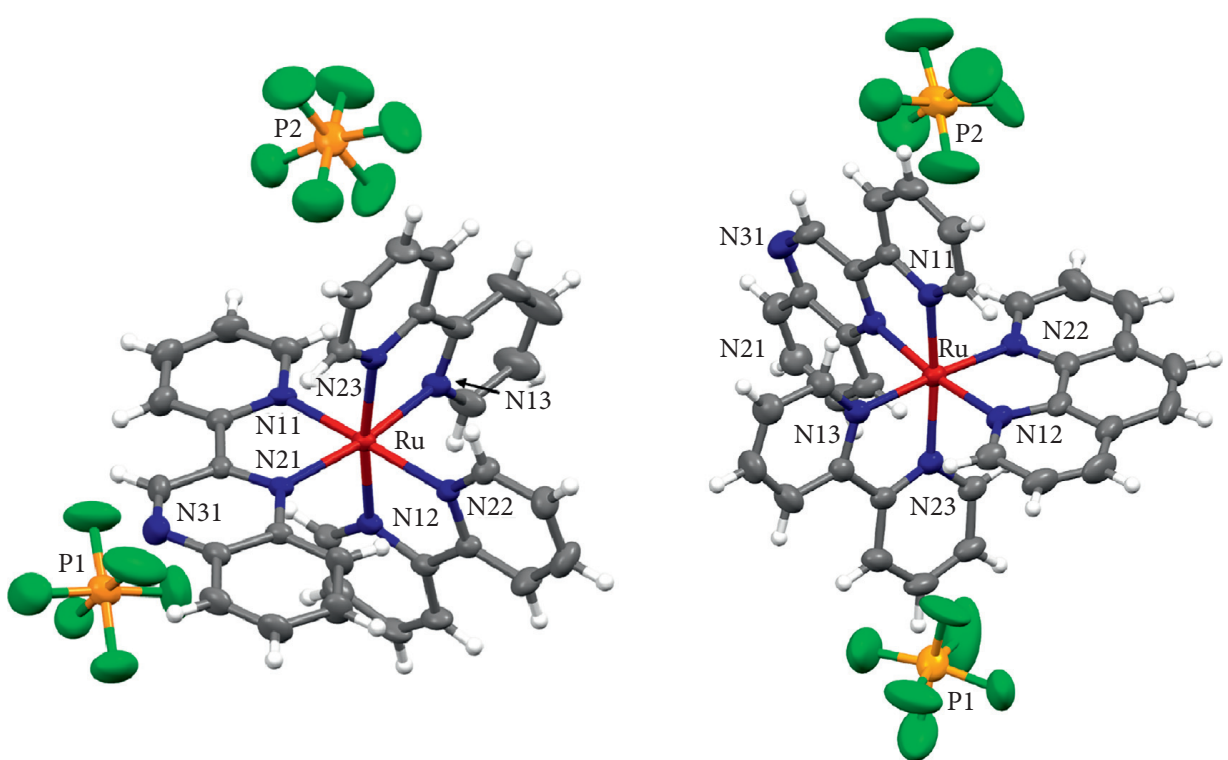

Figure 3: X-ray structures for complexes 1 and 2. Thermal ellipsoids are depicted at the 30\% probability level. Solvent molecules of crystallization were omitted for clarity.

TABLE 4: Selected Ru-N bond lengths $(\AA)$.

\begin{tabular}{lll}
\hline & 1 & 2 \\
\hline Ru-N11 & $2.063(5)$ & $2.048(5)$ \\
Ru-N21 & $2.119(5)$ & $2.098(5)$ \\
Ru-N23 & $2.073(5)$ & $2.069(5)$ \\
Ru-N13 & $2.061(5)$ & $2.065(5)$ \\
Ru-N22 & $2.073(5)$ & $2.062(5)$ \\
Ru-N12 & $2.075(5)$ & $2.060(5)$ \\
\hline
\end{tabular}

TABLe 5: Metal- $\mathrm{N}_{\text {quinoxaline }}$ and metal- $\mathrm{N}_{\text {pyridyl }}$ bond lengths $(\AA)$ for 2, 2'-pq complexes.

\begin{tabular}{lccc}
\hline Compound & Metal- $\mathrm{N}_{\text {quinoxaline }}$ & Metal- $_{\text {pyridyl }}$ & \\
\hline$\left[\mathrm{W}(\mathrm{CO})_{5}\left(2,2^{\prime}-\mathrm{pq}\right)\right]$ & 2.299 & 2.202 & Ref. \\
{$\left[\mathrm{Mo}(\mathrm{CO})_{5}\left(2,2^{\prime}-\mathrm{pq}\right)\right]$} & 2.300 & 2.220 & {$[50]$} \\
{$\left[\operatorname{Re}(\mathrm{CO})_{5}\left(\mathrm{Cl}-2,2^{\prime}-\mathrm{pq}\right) \mathrm{Cl}\right]$} & 2.230 & 2.175 & {$[46]$} \\
{$\left[\operatorname{Re}(\mathrm{CO})_{5}\left(2,2^{\prime}-\mathrm{pq}\right) \mathrm{Br}\right]$} & 2.220 & 2.145 & {$[47]$} \\
{$\left[\mathrm{Pt}\left(2,2^{\prime}-\mathrm{pq}\right) \mathrm{Cl}_{2}\right]$} & 2.079 & 2.029 & {$[48]$} \\
{$\left[\mathrm{Ag}\left(2,2^{\prime}-\mathrm{pq}\right)_{2}\right] \mathrm{ClO}_{4}$} & 2.260 & 2.407 & {$[51]$.} \\
{$\left[\mathrm{Ru}(\mathrm{bpy})_{2}\left(2,2^{\prime}-\mathrm{pq}\right)\right]\left(\mathrm{PF}_{6}\right)_{2}(1)$} & 2.119 & 2.063 & This study \\
{$\left[\mathrm{Ru}(\mathrm{bpy})(\mathrm{phen})\left(2,2^{\prime}-\mathrm{pq}\right)\right]\left(\mathrm{PF}_{6}\right)_{2}(2)$} & 2.097 & 2.049 & \\
\hline
\end{tabular}

3.5.2. Absorption Titration. The absorption spectra of ratios in Tris- $\mathrm{HCl}$ buffer with constant concentration of the complex $(20 \mu \mathrm{M})$ and increasing concentration of DNA from 0 to $400 \mu \mathrm{M}$ can be found at Figure 5. The absorbance peaks at $488 \mathrm{~nm}$ and $514 \mathrm{~nm}$ attributed to MLCT transitions of the complex, after the addition of specific amounts of DNA, continuously increased with a hypsochromic shift. Furthermore, the intensity of bands at $345 \mathrm{~nm}$ and $380 \mathrm{~nm}$, which are attributed to ILCT transitions [22], shows a similar behavior with the MLCT of complex 2. Hyperchromism with a very slight blue shift can be attributed to the adoption of the appropriate conformation of the complex in which the aromatic system of the rings could connect by bonds that match the torsion of the grooves of DNA. It can be well assumed that such interaction affects the absorption bands of the complex, by the hyperchromism observed at $514 \mathrm{~nm}$ in about $50 \%$, which suggests that the complex interacts with DNA by groove binding.

The binding constant $K_{\mathrm{b}}$ was calculated, from three different experiments, as the ratio of slope of the plot of (DNA) $/\left(\varepsilon_{a}-\varepsilon_{f}\right)$ vs. (DNA) to the intercept at $514 \mathrm{~nm}$ and equals to $4.46 \times 10^{5} \mathrm{M}^{-1}$ (Table 6 ). This value shows a great binding affinity for DNA and comes in agreement with other metal complexes that contain the $2,2^{\prime}$-pq ligand [59]. In addition, this value is greater than the $K_{\mathrm{b}}$ for $\left[\mathrm{Ru}(\mathrm{bpy})_{2}(-\right.$ phen $)]^{2+},\left[\operatorname{Ru}(\text { bpy })_{3}\right]^{2+}$, and $\left[\operatorname{Ru}(\text { phen })_{3}\right]^{2+}$, which equals to 


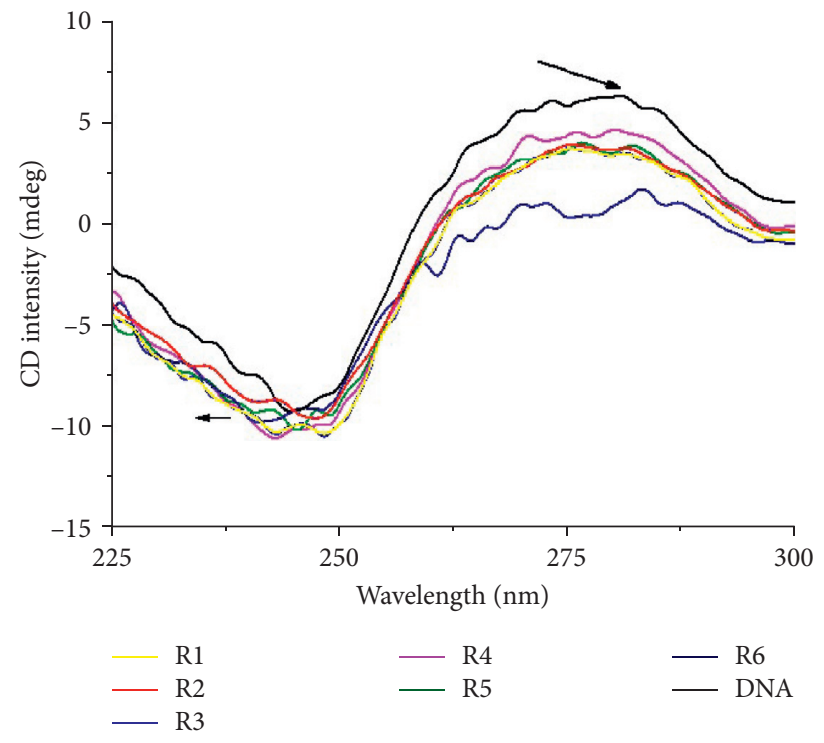

FIGURE 4: CD spectrum of DNA in the presence of complex 2.

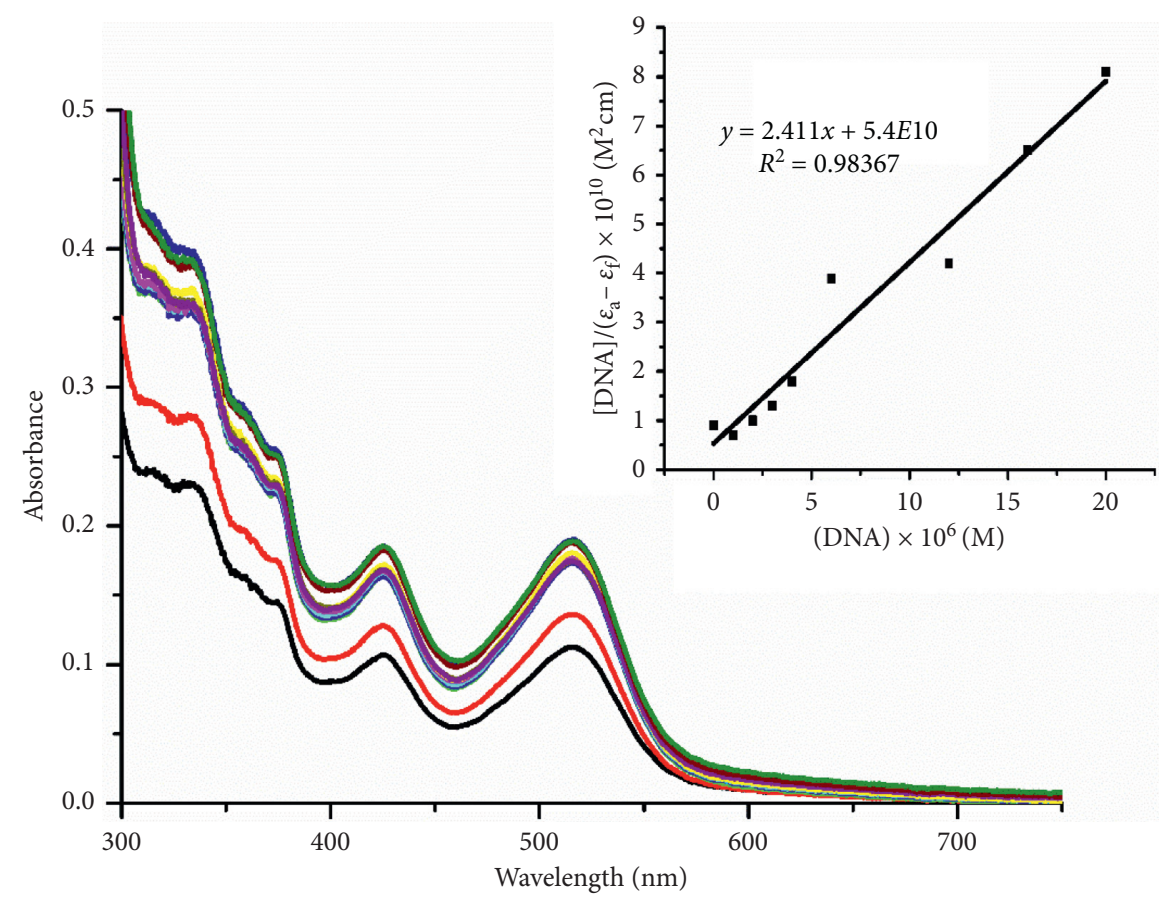

FIgURE 5: Absorption titration for complex 2 with DNA.

TABLE 6: Binding constants and Stern-Volmer quenching constants of Ru (II) complexes at $25^{\circ} \mathrm{C}$.

\begin{tabular}{|c|c|c|c|c|c|c|}
\hline Compound & $K_{\mathrm{b}}\left(\mathrm{M}^{-1}\right)$ & $\mathrm{K}_{\mathrm{SV}}\left(\mathrm{M}^{-1}\right)$ & $K_{\mathrm{q}}\left(\mathrm{M}^{-1} \mathrm{~s}^{-1}\right)$ & $\mathrm{K}_{\mathrm{app}}\left(\mathrm{M}^{-1}\right)$ & Binding mode & References \\
\hline 1 & & 0.87 & $3.4 \cdot 10^{11}$ & $6 \cdot 10^{4}$ & & \\
\hline 2 & $4.46 \cdot 10^{5}$ & 0.96 & $1.8 \cdot 10^{12}$ & $9 \cdot 10^{4}$ & & \\
\hline$\left[\operatorname{Ru}(\text { phen })_{2}\left(\mathrm{~cd} 2,2^{\prime}-\mathrm{pq}\right)\right]^{+2}$ & $4.6710^{3}$ & 0.052 & & $4.67 \cdot 10^{3}$ & Groove binding & {$[56]$} \\
\hline$\left[\mathrm{RuCl}_{3}(\mathrm{dmso})(\right.$ phen $\left.)\right]$ & & 3.03 & & $6.9 \cdot 10^{6}$ & Intercalation & {$[57]$} \\
\hline$\left[\mathrm{RuCl}_{3}(\mathrm{dmso})\right.$ (bpy)] & & 1.73 & & $3.43 \cdot 10^{6}$ & & [57] \\
\hline$\left[\mathrm{RuCl}_{3}(\mathrm{dmso})(\mathrm{dppz})\right]$ & & 4.47 & & $8.62 \cdot 10^{6}$ & Intercalation & [57] \\
\hline$\left[\operatorname{Ru}(\text { aeip })_{2}(\text { Haip })\right]^{2+}$ & $4.47 \cdot 10^{6}$ & 3.26 & & & Groove binding & {$[58]$} \\
\hline
\end{tabular}


9.1.10 $0^{3} \mathrm{M}^{-1}, 0.248 \cdot 10^{4} \mathrm{M}^{-1}$, and $0.349 \cdot 10^{4} \mathrm{M}^{-1}$, respectively $[3,60,61]$, indicating that the $2,2^{\prime}$-pq ligand plays a significant role in the interactions with DNA. On the other hand, the $\mathrm{Kb}$ of 2 is ten times lower than the $\mathrm{Kb}$ of typical intercalators as $\left[\mathrm{Ru}(\mathrm{bpy})_{2}(\mathrm{dppz})\right]^{2+}\left(K_{\mathrm{b}}>10^{6} \mathrm{M}^{-1}\right)$ [62] and $\left[\mathrm{Ru}(\mathrm{phen})_{2}(\mathrm{dppz})\right]^{2+}\left(K_{\mathrm{b}}=6 \cdot 10^{7} \mathrm{M}^{-1}\right) \quad[63]$ and further supports a groove binding mode. Furthermore, by applying the equation $\Delta \mathrm{G}=-\mathrm{RT} \ln \mathrm{K}_{\mathrm{b}}$, where $R$ is the gas constant, $T=298 \mathrm{~K}$, and $K_{\mathrm{b}}$ is the calculated binding constant, $\Delta \mathrm{G}$ is calculated at $-32.22 \mathrm{KJ} / \mathrm{mol}^{-1}(-7.7 \mathrm{Kcal} / \mathrm{mol})$, indicating a spontaneous interaction among the complex and the CTDNA, whereas for $\mathrm{EB}$, the $\Delta \mathrm{G}$ value is estimated at $-8.7 \mathrm{Kcal} /$ mol [64].

3.5.3. Viscosity Measurements. Viscosity measurements were performed to further probe the interaction between 2 and CT-DNA. In order to test the reproducibility of the results, three different measurements were taken for each ratio differing less than $0.3 \mathrm{~s}$. Figure 6 shows the relative viscosity of DNA versus $r$ ratio. A glaring decrease is observed, up to 0.68 , as the concentration of complex increases, corroborating previous indications that the complex binds in the grooves of the double helix reducing its effective length, hence its viscosity. Thus, an intercalative DNA binding mode could unequivocally be excluded.

3.5.4. Competitive Studies with Ethidium Bromide. With an increasing amount of complexes 1 and 2, a decrease in the emission intensity is observed (Figure 7, Figure S3 for 1), which is associated to the competitive ability of the complexes. Also, at high concentrations $\left(c>2 \cdot 10^{-4} \mathrm{M}\right)$, complexes 1 and 2 destabilize the DNA-EB complex, leading to a significant decrease in fluorescence emission. The extent of fluorescence quenching of EB-DNA does not reflect the extent of the intercalative mode of ruthenium complexes because at lower or equal concentrations, only inadequate quenching is observed $(r=(\mathrm{EB}) /($ complex 2$)=1$ at $23 \%$ decrease in emission intensity). The quenching of bound EBDNA can be attributed to potential energy or energy transfer reactions among it and the complexes. The quenching of EB bound to DNA by compounds 1 and 2 is in agreement with linear Stern-Volmer equation [65].

$$
I_{0} / I=1+K_{\mathrm{SV}}[\text { complex }]=1+K_{q} \tau_{\mathrm{o}}[Q]
$$

where $I_{\mathrm{o}}$ and $I$ represent the fluorescence intensities in absence and in presence of quencher, respectively; $\mathrm{K}_{\mathrm{sv}}$ is the Stern-Volmer constant; $K_{q}$ is the quenching rate constant; and $\tau_{o}$ is the average lifetime of DNA without the quencher molecule $\left(\tau_{o}=10^{-8} \mathrm{~s}\right)[65,66]$. From the slope of the regression line in the derived plot $\left(I_{\mathrm{o}} / I\right.$ vs. $r=$ (complex $) /$ (DNA)), the $\mathrm{K}_{\mathrm{SV}}$ value for each complex is calculated at $0.87 \mathrm{M}^{-1}$ and $0.96 \mathrm{M}^{-1}$ for 1 and 2 , respectively, indicating that 2 exhibits better affinity to CT-DNA, probably due to the phen moiety's contribution to the mechanism of the interaction. The $K_{\mathrm{sv}}$ values (Table 6) confirm groove binding and are in the same order of magnitude as other ruthenium complexes with groove binding ability $[67,68]$.

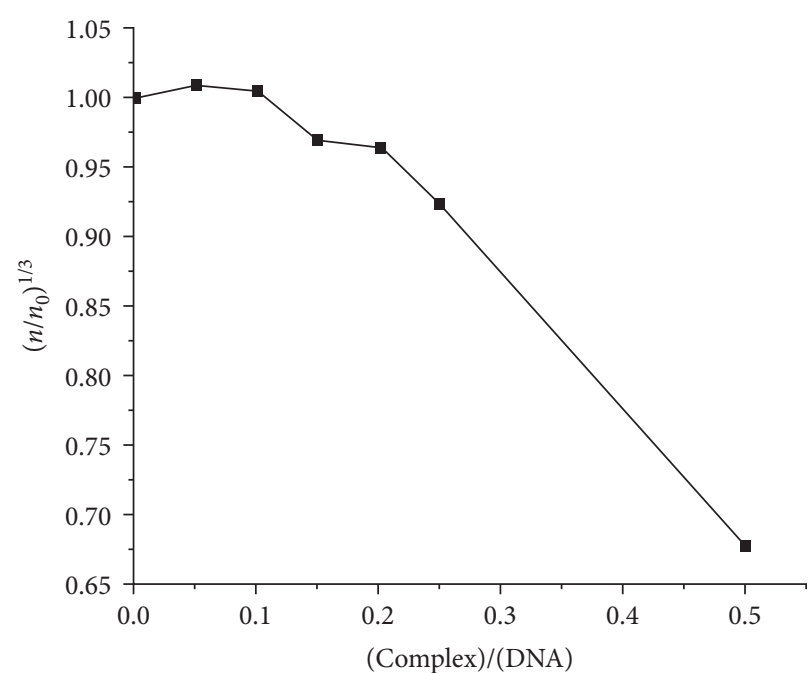

FIGURE 6: Relative viscosity of DNA versus DNA/complex 2 ratio.

Moreover, from equation (1), the quenching rate constant, $K_{q}$ is calculated as $10^{11} \mathrm{M}^{-1}$ and $10^{12} \mathrm{M}^{-1}$ for 1 and 2, respectively, pointing to a static quenching mechanism, since the limitation for the dynamic quenching process is at $K_{q}=2.0 \cdot 10^{8} \mathrm{M}^{-1}$. However, further experiments at different temperatures should be conducted to verify the quenching mechanism. On the other hand, the decrease in the intensity of emission is related to the binding affinity of the complexes to DNA and can be used to calculate their binding constant, following the equation $[69,70]$ :

$$
K_{\mathrm{EB}}[\mathrm{EB}]_{50 \%}=K_{\text {app }}[Q]_{50 \%} \text {, }
$$

where $K_{\mathrm{app}}$ is the apparent DNA binding constant of 1 or 2, $K_{\mathrm{EB}}$ is the DNA binding constant of EB (equals to $\left.1.25 \cdot 10^{6} \mathrm{M}^{-1}\right)$, and $[\mathrm{EB}]_{50 \%}$ and $[\mathrm{Ru}]_{50 \%}$ are the $\mathrm{EB}$ and complexes 1/or 2 concentrations at which $50 \%$ of $\mathrm{EB}$ molecules in EB-DNA were displaced [54]. As shown in Figure 8 , the decrease in the emission intensity up to $50 \%$ is at $R=3$ and $R=2$ for 1 and 2, respectively ( $R=$ (complex)/ (EB-DNA)) indicating that both complexes bind less strong than EB to DNA, therefore not displacing EB, and consequently, a groove binding mode is suggested. These findings come in accordance with the results of the above experiments.

3.5.5. Cytotoxicity Studies. In vitro studies tested the antiproliferative activity of 1 and 2 against MCF-7 cell line (human breast cancer cell line) and healthy (HEK-293, human embryonic kidney healthy cells 293). $\mathrm{IC}_{50}$ values of both complexes and cis-platin for both cell lines were calculated, and the results are summarized in Table 7. Between the two complexes, 2 presents the highest activity against MCF-7 cells $\left(\mathrm{IC}_{50}=6.2 \pm 1.2 \mu \mathrm{M}\right)$, almost equal to cis-platin $\left(\mathrm{IC}_{50}=5.19 \pm 0.8 \mu \mathrm{M}\right)$; whereas, both complexes cause almost no apoptosis to HEK-293 (at least, to the tested concentrations). The presence of phen ligand also induces a difference in activity of 2 compared to 1 , which can be attributed to the greater hydrophobicity of phen compared 


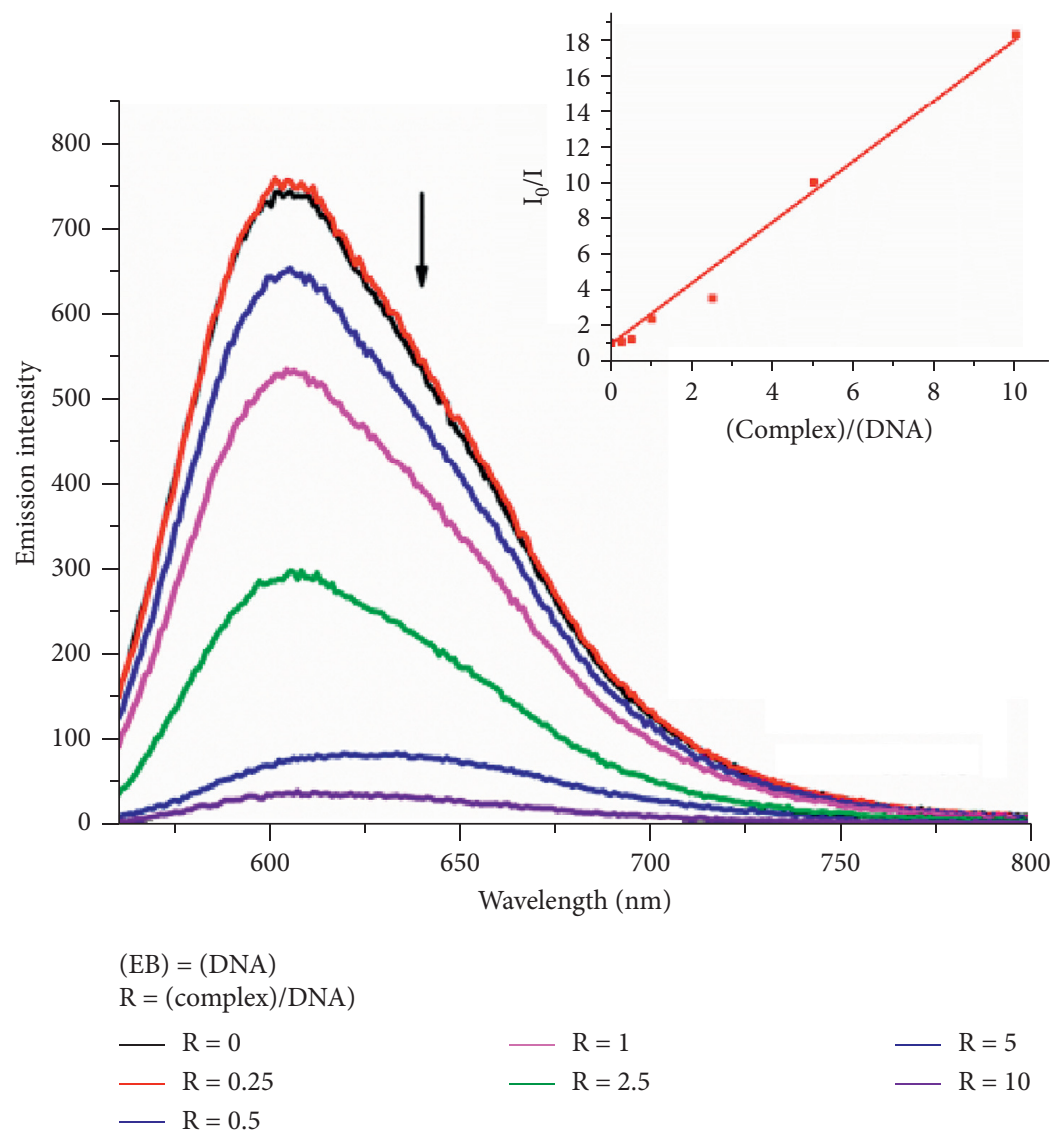

Figure 7: Emission spectra of EB bound to DNA with increasing amount of 2. $(\mathrm{EB})=(\mathrm{DNA})=1 \cdot 10^{-4} \mathrm{M}\left[\mathrm{Ru}(\mathrm{bpy})(\mathrm{phen})\left(2,2^{\prime}-\mathrm{pq}\right)\right]^{2+}=0$ $10 \cdot 10^{-4} \mathrm{M} \lambda_{\mathrm{ex}}=526 \mathrm{~nm}$, in tris-HCl buffer solution. Stern-Vomer plot of $I_{0} / I$ vs. $\mathrm{r}$ (where $r=($ complex 2$) /(\mathrm{DNA})$ ) of the fluorescence titration.

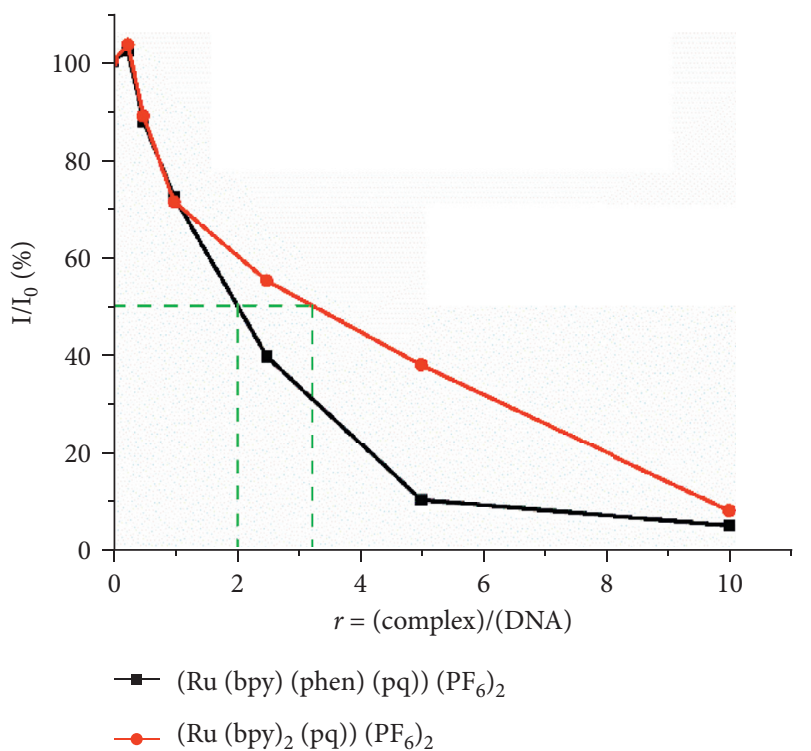

Figure 8: The $\%$ relative intensity of fluorescence emission of EB at $\lambda_{\mathrm{em}}=605 \mathrm{~nm}$ vs. $\mathrm{r}(r=($ complex $) /(\mathrm{CT}-\mathrm{DNA}))$ for the complexes 1 and 2 in tris-HCL buffer $(150 \mathrm{mM} \mathrm{NaCl}, \mathrm{pH}=7.4)$. 
TABLE 7: In vitro activity of 1,2 , and cis-platin (expressed as $\mathrm{IC}_{50}(\mu \mathrm{M})$ against MCF-7 cells).

\begin{tabular}{|c|c|c|c|}
\hline Complexes & MCF-7 & HEK-293 & References \\
\hline $1^{*}$ & $10.5 \pm 0.9$ & n.a & \\
\hline $2^{*}$ & $6.2 \pm 1.2$ & n.a & \\
\hline Cis-platin & $5.19 \pm 0.8$ & $6.53 \pm 1.1$ & \\
\hline$\left[\mathrm{Ru}(\mathrm{bip})_{2} \mathrm{Cl}_{2}\right]$ & $134.9 \pm 7.9$ & & {$[71]$} \\
\hline$\left[\mathrm{Ru}(\mathrm{bmp})_{2} \mathrm{Cl}_{2}\right]$ & $>200$ & & {$[71]$} \\
\hline$\left[\mathrm{RuCl}_{3}(\mathrm{dmso})(\mathrm{bpy})\right]$ & 691 & & {$[57]$} \\
\hline$\left[\mathrm{RuCl}_{3}(\mathrm{dmso})\right.$ (phen) $]$ & 679 & & {$[57]$} \\
\hline cis- $\left[\mathrm{Ru}(\mathrm{bpy})_{2} \mathrm{Cl}_{2}\right]$ & 189.2 & & {$[72]$} \\
\hline cis- $\left[\mathrm{Ru}(\text { phen })_{2} \mathrm{Cl}_{2}\right]$ & $>200$ & & {$[72]$} \\
\hline$\left[\mathrm{Cu}(\mathrm{pq})\left(\mathrm{NO}_{3}\right)\right] \mathrm{NO}_{3}$ & $17.4 \pm 1.1$ & & [59] \\
\hline$\left[\mathrm{Cu}(\mathrm{pq})_{2}\left(\mathrm{NO}_{3}\right)\right] \mathrm{NO}_{3} \cdot 6 \mathrm{H}_{2} \mathrm{O}$ & $4.92 \pm$ & & [59] \\
\hline
\end{tabular}

*The cytotoxicity study is performed on amorphous material. The IC50 values are the average of three separate experiments. n.a., not active (IC $50>100 \mu \mathrm{M})$;
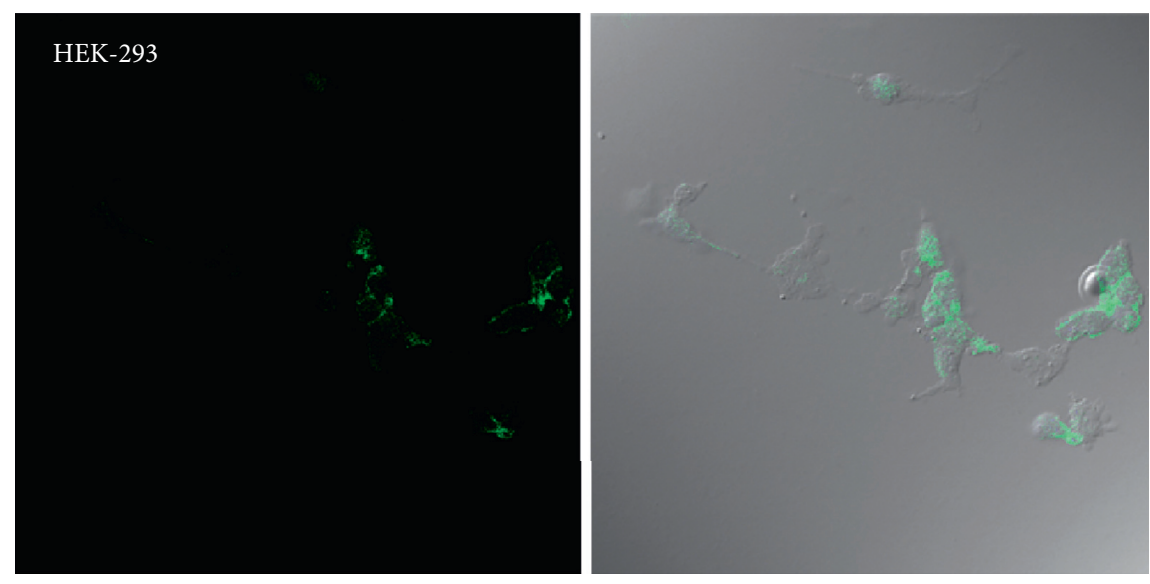

(a)
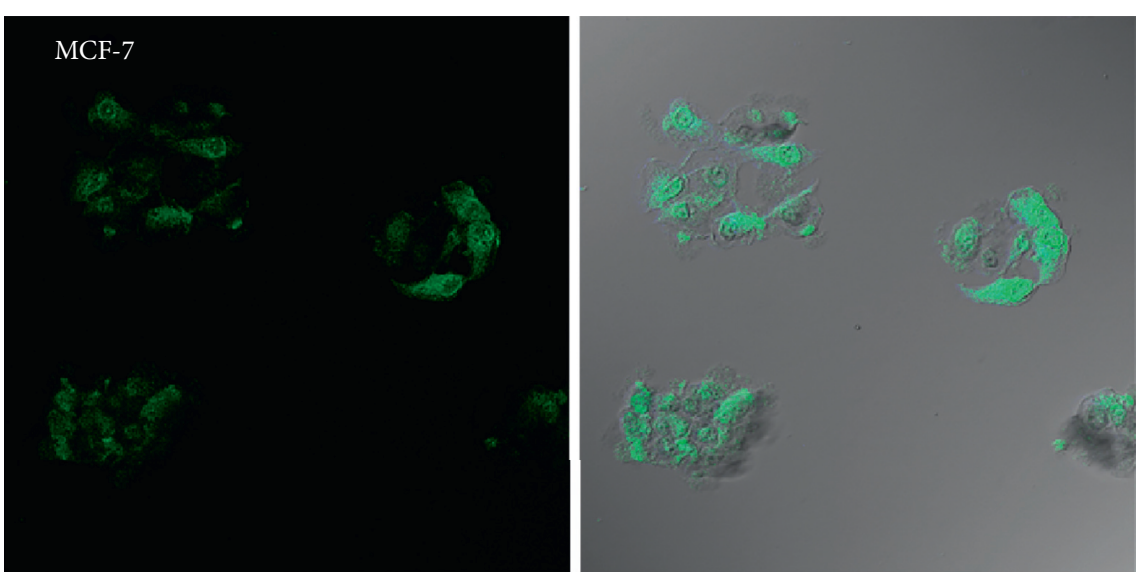

(b)

FIGURE 9: Confocal microscopy images of 2 about cellular uptake and the localization mode in healthy (HEK-293) (a) and breast cancer cells (MCF-7) (b).

to bpy and at the same time highlights the potency of fused heterocyclic moieties in designing metallodrugs [73]. The observed antitumor activity of both complexes is better than other reported bis-1,10-phenanthroline or bipyridyl $\mathrm{Ru}$ complexes and comparable with other metallodrugs carrying the $2,2^{\prime}$-pq ligand (Table 7 ), highlighting the potency of $2,2^{\prime}$ pq moiety in antiproliferative activity.
Besides, confocal images (Figure 9) indicate that complexes 1 and 2 can localize on both cell lines, and the localization mode depends on the cell line. Thus, in HEK-293, complex 2 is localized on the cytoplasm; whereas, it is localized both on the cytoplasm and nucleus to MCF-7 cells. The latter indicates that 2 internalizes most efficiently in MCF-7 cells and can act as an antitumor agent. 
TABLE 8: Molecular docking studies for 1 and 2 with the sequence (TCATAAATGTATCTAAGTAG) 2 (pdb code: 5D2Q) and (ACCGACGTCGGT) $)_{2}$ (pdb code: 423D).

\begin{tabular}{|c|c|c|c|c|c|c|}
\hline $\begin{array}{l}\text { Pdb } \\
\text { code }\end{array}$ & Complexes & $\begin{array}{l}\text { Ligand } \\
\text { moiety }\end{array}$ & $\begin{array}{c}\text { Binding energy } \\
\left(\mathrm{kcal} \cdot \mathrm{mol}^{-1}\right)\end{array}$ & $\begin{array}{c}\text { Intermolar energy } \\
\left(\mathrm{kcal} \cdot \mathrm{mol}^{-1}\right)\end{array}$ & $\begin{array}{c}\text { Electrostatic energy } \\
\left(\mathrm{kcal} \cdot \mathrm{mol}^{-1}\right)\end{array}$ & $\begin{array}{l}\text { Inhibition constant } \\
(\mu \mathrm{M})\end{array}$ \\
\hline \multirow{3}{*}{$5 \mathrm{D} 2 \mathrm{Q}$} & (1) & $2,2^{\prime}-\mathrm{pq}$ & -7.03 & -7.03 & -0.04 & 7.05 \\
\hline & \multirow{2}{*}{ (2) } & phen & -7.33 & -7.33 & -0.04 & 4.22 \\
\hline & & $2,2^{\prime}-\mathrm{pq}$ & -7.18 & -7.18 & -0.08 & 5.49 \\
\hline \multirow{3}{*}{$423 \mathrm{D}$} & \multirow{3}{*}{$\begin{array}{l}(1) \\
(2)\end{array}$} & 2,2 -pq & -6.76 & -6.76 & -0.08 & 11.02 \\
\hline & & phen & - & - & - & - \\
\hline & & $2,2^{\prime}-\mathrm{pq}$ & -6.19 & -6.19 & -0.07 & 29.22 \\
\hline
\end{tabular}

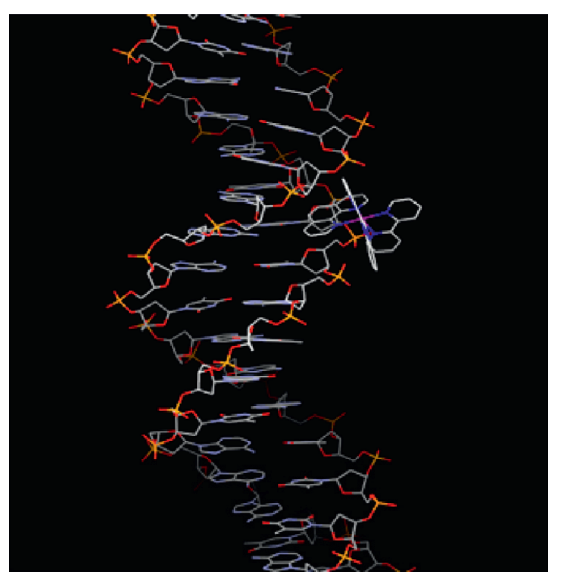

(a)

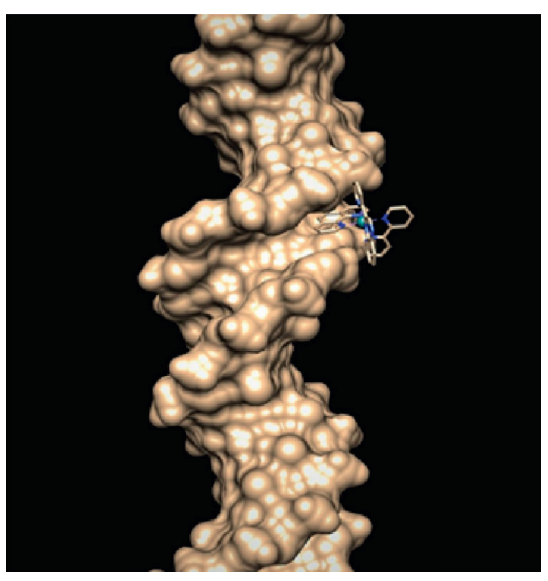

(b)

FIGURE 10: (a) Visualization of the interaction of 2 via phen moiety to the specific region of the sequence of DNA (5D2Q). (b) Interaction of complex 2 through the phen moiety with the hydrophobic DNA sequence (PDB: 5D2Q).

3.5.6. Molecular Docking of the Complex with DNA Sequence. Molecular docking is an appealing technique to shed light into drug-biomolecule interactions. Taking into account the experimental data of DNA binding for 1 and 2, molecular docking studies were performed in order to identify the most preferable binding site on the biomolecule, assuming that DNA and ruthenium complexes are rigid. Complex 1 was already studied through $1 \mathrm{D}$ and $2 \mathrm{D} \mathrm{NMR}$, indicating that both isomers $\Lambda$ - and $\Delta$-interact with oligonucleotides by the same mode and can provide us a good indicator for our docking calculations [21]. The selected optimized structures of complexes 1 and 2 obtained from DFT calculations in the gas phase were used in docking experiments, utilizing crystallography data. A series of DNA duplex sequences known for groove binding were tested, and the ones with the lower (more stable) energy are given thereafter. The results of docking are presented in Table 8 and confirm the experimental data. According to our docking calculations, both complexes 1 and 2 interact successfully with DNA duplex sequences (TCATAAATGTATCTAAGTAG) 2 and (ACCGACGTCGGT) ${ }_{2}$ by minor groove binding. Actually, complex 2 docks to the former sequence by two different modes, through the $\pi$-aromatic system of phen and $2,2^{\prime}$-pq within the T-A (Figure 10) and $\mathrm{C}-\mathrm{T}$ regions (Figure 11), respectively. Moreover, in nine out of twenty runs, binding is performed through the $\pi$-aromatic system of $2,2^{\prime}$-pq, which interacts with the aromatic system of thymine T4 of B-helix.
On the other hand, the $\pi$-aromatic system of phen interacts both with the aromatic systems of the sugar and the thymine T12 of B-helix. The bpy moiety does not intercalate but points across to the opposite strand. These results are in accordance with the fact that regions of $\mathrm{A}-\mathrm{T}$ bases are suitable for ligands making optimal Van der Waals contacts and with the literature of $\mathrm{Ru}(\mathrm{II})$-diimine complexes $[23,74,75]$. The binding energy is at $-7.33 \mathrm{kcal}^{\prime} \cdot \mathrm{mol}^{-1}$ and $-7.18 \mathrm{kcal} \cdot \mathrm{mol}^{-1}$ when 2 binds through phen and 2, 2'- pq ligand, respectively. These conclusions are in accordance with the calculated $\Delta G$ from the data of $U V-V$ is (vide supra).

As far as (ACCGACGTCGGT) ${ }_{2}$ sequence is concerned, the binding sites are slightly different, since the $\pi$-aromatic system of benzene ring of $2,2^{\prime}$-pq moiety of 2 matches with the $\pi$-aromatic system of cytosine of A-helix of DNA (423D : A : DC9) but not with phen, which stands against the hydrophilic chain (Figure S4). Van der Waals interactions enhance the stabilization of complex with DNA. On the other hand, complex 1 adducts with both sequences of DNA via 2, $2^{\prime}-\mathrm{pq}$ moiety and the binding energy is $-7.03 \mathrm{Kcal} \cdot \mathrm{mol}^{-1}$ and $-6.76 \mathrm{kcal} \cdot \mathrm{mol}^{-1}$, respectively $(\mathrm{Ta}-$ ble 8). Regarding the (TCATAAATGTATCTAAGTAG) sequence, the $\pi$-aromatic system of $2,2^{\prime}$-pq of 1 interacts with the $\pi$-aromatic system of thymine of the B-helix of DNA (5D2Q : B:DT16) (Figure 12); whereas, it interacts with the (ACCGACGTCGGT) 2 sequence through the $\pi$-aromatic thymine of the A-helix of DNA (423:B:DT20) (Figure S5). 


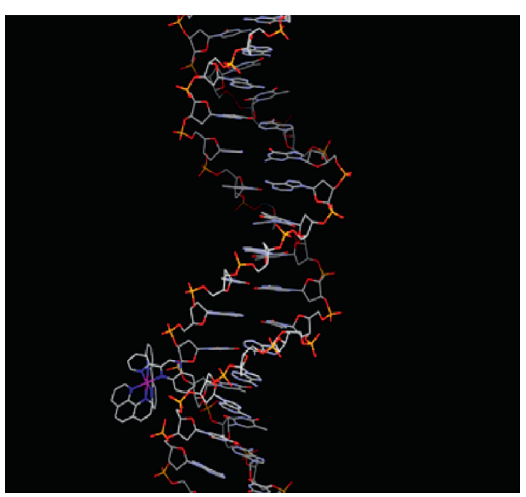

(a)

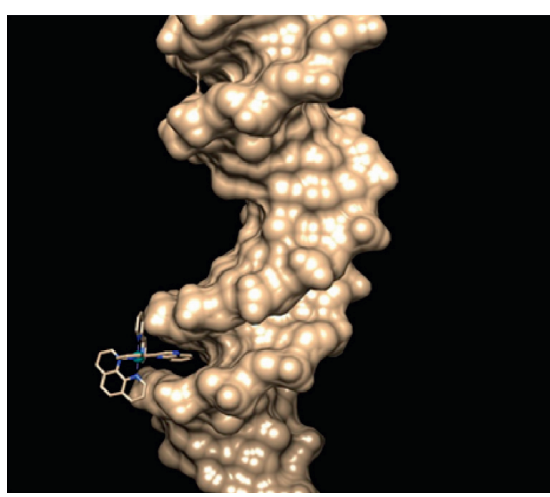

(b)

Figure 11: (a) Visualization of the interaction of 2 via 2, 2'-pq moiety to the specific region of the sequence of DNA (5D2Q). (b) Interaction of complex 2 through the 2, 2'-pq moiety with the hydrophobic DNA sequence (PDB: 5D2Q).

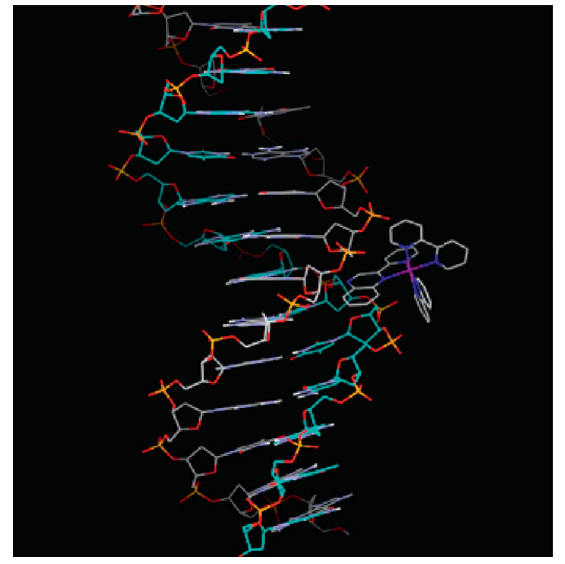

(a)

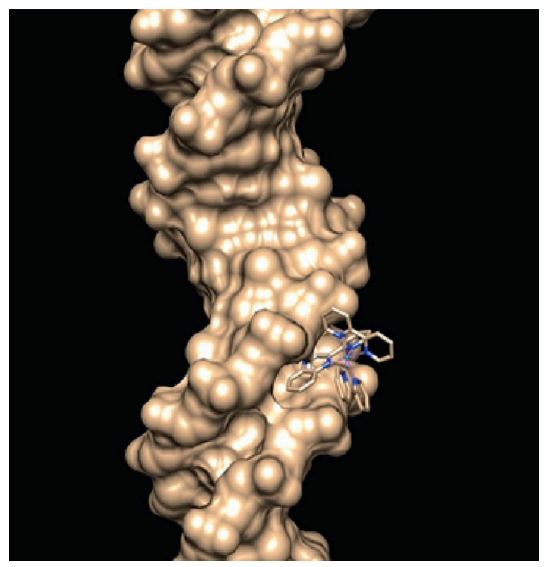

(b)

FIgURE 12: (a) Visualization of the interaction of 1 via 2, 2'-pq moiety to the specific region of the sequence of DNA (PDB: 5D2Q). (b) Interaction of complex 1 through 2, 2'-pq moiety with the hydrophobic DNA sequence (PDB: 5D2Q).

TABLE 9: Molecular docking studies for 1 and 2 with the sequence (ACCGACGTCGGT) 2 (pdb code: 423D).

\begin{tabular}{lccc}
\hline Atoms that participate & Distances & Energy \\
\hline A :DG67:21 and N of quinoxaline & 1.783 & 7.683 & - \\
& - & 1 & 2 \\
\hline
\end{tabular}

Simultaneously, a strong H-bond and average bond length $1.765 \AA$ is formed between the hydrogen atom of guanine (A : DG67:21) and the nitrogen of quinoxaline (Figure S6, Table 9). This is in accordance with previous findings for complex 1 [23]. Additionally, NMR studies in ruthenium complexes substituted with $2,2^{\prime}$-pq ligand reveal the minor groove binding mode. The octahedral geometry of ruthenium complexes does not favor the efficient interference of the bulkier $2,2^{\prime}$-pq ligand [76].

\section{Conclusions}

In conclusion, two heteroleptic ruthenium (II) polypyridyl complexes, 1 and 2, were prepared in an efficient, stepwise manner, and their photophysical and electrochemical properties were investigated. The electrochemical data reveal that the trisheteroleptic complex is easily reduced than its bis-analog based on the different electronic properties of the ligands. Complex 2 interacts with cellular DNA via the minor groove binding mode as evidenced by various spectroscopic techniques, hydrodynamic experiments, and molecular docking studies. The interaction of 1 with DNA had been previously reported by NMR spectroscopy but is well documented through this study. The docking experiments reveal that both complexes interact as minor groove binders with the duplex sequences (TCATAAATGTATCTAAGTAG) ${ }_{2}$ and (ACCGACGTCGGT) with some differences in the binding mode. Complex 2 
binds through the $2,2^{\prime}$-pq and phen ligand with the former to prefer the thymine and the sugar bases and the latter cytosine site. The theoretical calculated binding energies are in agreement with the experimental one $\left(-7.7 \mathrm{kcal} \bullet \mathrm{mol}^{-1}\right)$. On the other hand, 1 interacts with both sequences through $2,2^{\prime}-\mathrm{pq}$ ligand with a preference to thymine. Finally, in vitro experiments reveal the significant role of the $2,2^{\prime}-\mathrm{pq}$ in the cytotoxicity of both complexes. Both complexes act as promising antitumor agents with complex 2 to localize in the nucleus and have better activity than 1 and cis-platin. More extensive theoretical studies are underway for a rational ligand design of metallodrugs.

\section{Abbreviations}

aeip: $\quad 2$-(Anthracen-9-yl)-1-ethyl-imidazo[4,5-f][1, 10] phenanthroline

${ }^{1} \mathrm{H} \quad$ Proton nuclear magnetic resonance spectroscopy

NMR:

bpy: $\quad 2,2^{\prime}$-Bipyridine phen $=1,10$-phenanthroline

2: $\quad 2^{\prime}-\mathrm{pq}=2-\left(2^{\prime}\right.$-Pyridyl $)$-quinoxaline

CD: Circular dichroism

CT- Calf thymus DNA

DNA:

dip: 4,7-Diphenyl-1,10-phenanthroline

dmp: 2,9-Dimethyl-1,10-phenanthroline

DMF: $\quad N, N$-Dimethylformamide

DMSO: Dimethylsulfoxide

EB: $\quad$ Ethidium bromide

Haip: $\quad$ 2-(9-Anthryl)-1H-imidazo[4,5-f] $[1,10]$

phenanthroline

HEK- Human embryonic kidney healthy cells 293

293:

HRMS: High resolution mass spectroscopy

ILCT: Interligand charge transfer

$\mathrm{K}_{\mathrm{SV}}$ : $\quad$ Stern-Volmer constant

MCF-7: Cell line (human breast cancer cell line

MLCT: Metal-to-ligand charge transfer

MTT: Methyl thiazolyl tetrazolium

PAF: $\quad$ Platelet activating factor

TGA: Thermogravimetric analysis.

\section{Data Availability}

Crystallographic data for the structures reported in this study are deposited with the Cambridge Crystallographic Data Centre under the CCDC numbers: 2052212 ([Ru(bpy) 2(2, $2^{\prime}$-pq)](PF6)2 (1)) and 2052213 ([Ru(bpy) (phen) $\left(2,2^{\prime}\right.$ pq)](PF6)2 (2)). Copies of these data can be obtained free of charge from http://www.ccdc.cam.ac.uk/data_request/cif.

\section{Conflicts of Interest}

The authors declare that there are no conflicts of interest.

\section{Authors' Contributions}

Sofia Balou and Athanasios Zarkadoulas contributed equally to this study.

\section{Acknowledgments}

This work was financially supported by the Special Research Account of National and Kapodistrian University of Athens (15244). This study was based upon a work from COST Action 15135 supported by European Cooperation in Science and Technology. The authors would also like to thank the Laboratory of Analytical Chemistry, Chemistry Department of NKUA, and Dr D.E. Damalas and Prof. Nikolaos Thomaidis for their contribution to the HRMS techniques. Assistance of the Ph.D candidate A. K. Plessas in TGA measurements is also appreciated.

\section{Supplementary Materials}

Crystallographic data for the structures reported in this study are deposited with the Cambridge Crystallographic Data Centre under the CCDC numbers: 2052212 ([Ru(bpy) $\left.\left.2\left(2,2^{\prime}-\mathrm{pq}\right)\right](\mathrm{PF} 6) 2(1)\right)$ and 2052213 ([Ru(bpy) (phen) $\left(2,2^{\prime}\right.$ pq)](PF6)2 (2)). Copies of these data can be obtained free of charge from http://www.ccdc.cam.ac.uk/data_request/cif. (Supplementary Materials)

\section{References}

[1] N. Elgrishi, M. B. Chambers, X. Wang, and M. Fontecave, "Molecular polypyridine-based metal complexes as catalysts for the reduction of CO2," Chemical Society Reviews, vol. 46, no. 3, pp. 761-796, 2017.

[2] Y.-J. Yuan, Z.-T. Yu, D.-Q. Chen, and Z.-G. Zou, "Metalcomplex chromophores for solar hydrogen generation," Chemical Society Reviews, vol. 46, no. 3, pp. 603-631, 2017.

[3] S. Nehru, S. Veeralakshmi, S. Kalaiselvam, S. P. Subin David, J. Sandhya, and S. Arunachalam, "DNA binding, antibacterial, hemolytic and anticancer studies of some fluorescent emissive surfactant-ruthenium(II) complexes," Journal of Biomolecular Structure and Dynamics, vol. 39, no. 6, pp. 2242-2256, 2020.

[4] X.-W. Liu, X. Yang, W.-G. Peng et al., "New designed DNA light switch Ruthenium complexes as DNA photocleavers and Topoisomerase I inhibitors," Applied Organometallic Chemistry, vol. 32, Article ID e4231, 2018.

[5] G. Liao, X. Chen, J. Wu et al., "Ruthenium(ii) polypyridyl complexes as dual inhibitors of telomerase and topoisomerase," Dalton Transactions, vol. 44, no. 34, pp. 15145-15156, 2015.

[6] K. Arora, M. Herroon, M. H. Al-Afyouni et al., "Catch and release photosensitizers: combining dual-action ruthenium complexes with protease inactivation for targeting invasive cancers," Journal of the American Chemical Society, vol. 140, no. 43, pp. 14367-14380, 2018.

[7] J. K. White, R. H. Schmehl, and C. Turro, "An overview of photosubstitution reactions of $\mathrm{Ru}(\mathrm{II})$ imine complexes and their application in photobiology and photodynamic therapy," Inorganica Chimica Acta, vol. 454, pp. 7-20, 2017.

[8] B. Liu, Y. Gao, M. A. Jabed, S. Kilina, G. Liu, and W. Sun, "Lysosome targeting bis-terpyridine ruthenium(II) complexes: photophysical properties and in vitro photodynamic therapy," ACS Applied Bio Materials, vol. 3, no. 9, pp. 6025-6038, 2020.

[9] G. Li, L. Sun, L. Ji, and H. Chao, "Ruthenium(ii) complexes with dppz: from molecular photoswitch to biological 
applications," Dalton Transactions, vol. 45, no. 34, pp. 13261-13276, 2016.

[10] M. Kaplanis, G. Stamatakis, V. D. Papakonstantinou, M. Paravatou-Petsotas, C. A. Demopoulos, and C. A. Mitsopoulou, "Re(I) tricarbonyl complex of 1,10-phenanthroline-5,6-dione: DNA binding, cytotoxicity, anti-inflammatory and anti-coagulant effects towards platelet activating factor," Journal of Inorganic Biochemistry, vol. 135, pp. 1-9, 2014.

[11] S. Arounaguiri, D. Easwaramoorthy, A. Ashokkumar, A. Dattagupta, and B. G. Maiya, "Cobalt(III), nickel(II) and ruthenium(II) complexes of 1,10-phenanthroline family of ligands: DNA binding and photocleavage studies," Journal of Chemical Sciences, vol. 112, no. 1, pp. 1-17, 2000.

[12] C. A. Mitsopoulou, C. E. Dagas, and C. Makedonas, "Synthesis, characterization, DFT studies and DNA binding of mixed platinum (II) complexes containing quinoxaline and 1,2-dithiolate ligands," Journal of Inorganic Biochemistry, vol. 102, no. 1, pp. 77-86, 2008.

[13] C. A. Mitsopoulou, C. E. Dagas, and C. Makedonas, "Characterization and DNA interaction of the $\mathrm{Pt}(\mathrm{II})(\mathrm{pq})(\mathrm{bdt})$ complex: a theoretical and experimental research," Inorganica Chimica Acta, vol. 361, pp. 1973-1982, 2008.

[14] T. Kaushal, G. Srivastava, A. Sharma, and A. Singh Negi, "An insight into medicinal chemistry of anticancer quinoxalines," Bioorganic \& Medicinal Chemistry, vol. 27, no. 1, pp. 16-35, 2019.

[15] S. P. Perlepes, A. Garoufis, J. Sletten et al., "Preparation, structural characterization and physical properties of palladium(II) and platinum(II) complexes of the biheteroaromatic ligand 2-(2'-pyridyl)quinoxaline (L)," Inorganica Chimica Acta, vol. 261, no. 1, pp. 93-102, 1997.

[16] S. Tariq, K. Somakala, and M. Amir, "Quinoxaline: an insight into the recent pharmacological advances," European Journal of Medicinal Chemistry, vol. 143, pp. 542-557, 2018.

[17] J. A. Pereira, A. M. Pessoa, M. N. D. S. Cordeiro et al., "Quinoxaline, its derivatives and applications: a State of the Art review," European Journal of Medicinal Chemistry, vol. 97, pp. 664-672, 2015.

[18] C. A. Mitsopoulou and C. Dagas, "Synthesis, characterization, DNA binding, and photocleavage activity of oxorhenium (V) complexes with-diimine and quinoxaline ligands," Bioinorganic Chemistry and Applications, vol. 2010, Article ID 973742, 9 pages, 2010.

[19] B. J. Pages, Y. Zhang, F. Li, J. Sakoff, J. Gilbert, and J. R. Aldrich-Wright, "Cytotoxicity and structural analyses of 2,2'-bipyridine-, 4,4'-Dimethyl-2,2' -bipyr-idine- and 2-(2'pyridyl)quinoxalineplatinum(II) complexes," European Journal of Inorganic Chemistry, vol. 2015, no. 25, pp. 41674175, 2015.

[20] A. B. Tsoupras, A. Papakyriakou, C. A. Demopoulos, and A. I. Philippopoulos, "Synthesis, biochemical evaluation and molecular modeling studies of novel rhodium complexes with nanomolar activity against platelet activating factor," Journal of Inorganic Biochemistry, vol. 120, pp. 63-73, 2013.

[21] T. Tsolis, K. D. Papavasileiou, S. A. Divanis, V. S. Melissas, and A. Garoufis, "How half sandwich ruthenium compounds interact with DNA while not being hydrolyzed; A comparative study," Journal of Inorganic Biochemistry, vol. 160, pp. 12-23, 2016.

[22] A. Garoufis, A. Koutsodimou, N. Katsaros, C.-A. Mitsopoulou, and N. Hadjiliadis, "Mixed ligand Ru(II) complexes with 2,2'-bipyridine and 2-(2'-pyridyl)quinoxaline," Polyhedron, vol. 18, no. 3-4, pp. 361-369, 1998.
[23] A. Garoufis, G. Malandrinos, and N. Hadjiliadis, "NMR evidence for major groove binding of Both $\Lambda$ - and $\Delta-[\mathrm{Ru}(\mathrm{bpy})$ 2(pqx)](PF6)2 to the oligonucleotide d(CGCGAATTCGCG) 2," European Journal of Inorganic Chemistry, vol. 2004, no. 16, pp. 3326-3334, 2004.

[24] B. A. Albani, B. Peña, N. A. Leed et al., "Marked improvement in photoinduced cell death by a new tris-heteroleptic complex with dual action: singlet oxygen sensitization and ligand dissociation," Journal of the American Chemical Society, vol. 136, no. 49, pp. 17095-17101, 2014.

[25] S. P. Mulcahy, S. Li, R. Korn, X. Xie, and E. Meggers, "Solidphase synthesis of tris-heteroleptic ruthenium(II) complexes and application to acetylcholinesterase inhibition," Inorganic Chemistry, vol. 47, no. 12, pp. 5030-5032, 2008.

[26] S. S. Bhat, A. S. Kumbhar, N. Purandare et al., "Tris-heteroleptic ruthenium(II) polypyridyl complexes: synthesis, structural characterization, photophysical, electrochemistry and biological properties," Journal of Inorganic Biochemistry, vol. 203, Article ID 110903, 2020.

[27] M. M. da Silva, M. S. de Camargo, R. S. Correa et al., "Nonmutagenic $\mathrm{Ru}(\mathrm{ii})$ complexes: cytotoxicity, topoisomerase IB inhibition, DNA and HSA binding," Dalton Transactions, vol. 48, no. 39, pp. 14885-14897, 2019.

[28] S. Kasselouri, A. Garoufis, A. Katehanakis, G. Kalkanis, S. P. Perlepes, and N. Hadjiliadis, "1:1 Metal complexes of 2( 2 '-pyridyl)quinoxaline, a ligand unexpectedly formed by the reaction between 2-acetylpyridine and 1,2-phenylenediamine," Inorganica Chimica Acta, vol. 207, no. 2, pp. 255-258, 1993.

[29] B. P. Sullivan, D. J. Salmon, and T. J. Meyer, "Mixed phosphine 2,2'-bipyridine complexes of ruthenium," Inorganic Chemistry, vol. 17, no. 12, pp. 3334-3341, 1978.

[30] I. P. Evans, A. Spencer, and G. Wilkinson, "Dichlorotetrakis(dimethyl sulphoxide)ruthenium(II) and its use as a source material for some new ruthenium(II) complexes," Journal of the Chemical Society, Dalton Transactions, vol. 204, no. 2, pp. 204-209, 1973.

[31] A. Bruker, Smart, Bruker AXS Inc, Madison, WI, USA, 2012.

[32] M. C. Burla, R. Caliandro, M. Camalli et al., "SIR2004: an improved tool for crystal structure determination and refinement," Journal of Applied Crystallography, vol. 38, no. 2, pp. 381-388, 2005.

[33] G. M. Sheldrick, "A short history ofSHELX," Acta Crystallographica Section A Foundations of Crystallography, vol. 64, no. 1, pp. 112-122, 2007.

[34] L. J. Farrugia, "WinGXsuite for small-molecule single-crystal crystallography," Journal of Applied Crystallography, vol. 32, no. 4, pp. 837-838, 1999.

[35] C. F. Macrae, P. R. Edgington, P. McCabe et al., "Mercury: Visualization and analysis of crystal structures," Journal of Applied Crystallography, vol. 39, no. 3, pp. 453-457, 2006.

[36] E. K. Efthimiadou, C. Tapeinos, A. Chatzipavlidis et al., "Dynamic in vivo imaging of dual-triggered microspheres for sustained release applications: synthesis, characterization and cytotoxicity study," International Journal of Pharmaceutics, vol. 461, no. 1-2, pp. 54-63, 2014.

[37] D. Mulhern, S. Brooker, H. Görls, S. Rau, and J. G. Vos, "Synthesis of mononuclear and dinuclear ruthenium(ii) tris(heteroleptic) complexes via photosubstitution in bis(carbonyl) precursors," Dalton Transactions, no. 1, pp. 51-57, 2006.

[38] L. Spiccia, G. B. Deacon, and C. M. Kepert, "Synthetic routes to homoleptic and heteroleptic ruthenium(II) complexes 
incorporating bidentate imine ligands," Coordination Chemistry Reviews, vol. 248, no. 13-14, pp. 1329-1341, 2004.

[39] A. von Zelewsky and G. Gremaud, "Ruthenium(II) complexes with three different diimine ligands," Helvetica Chimica Acta, vol. 71, no. 5, pp. 1108-1115, 1988.

[40] S. M. Zakeeruddin, M. K. Nazeeruddin, R. Humphry-Baker, M. Grätzel, and V. Shklover, "Stepwise assembly of trisheteroleptic polypyridyl complexes of ruthenium(II)," Inorganic Chemistry, vol. 37, no. 20, pp. 5251-5259, 1998.

[41] R. C. van der Drift, J. W. Sprengers, E. Bouwman et al., "Ruthenium-catalyzed isomerization of allylic alcohols: oxidation state determines resistance against diene inhibition," European Journal of Inorganic Chemistry, vol. 2002, no. 8, pp. 2147-2155, 2002.

[42] D. L. Ashford, C. R. K. Glasson, M. R. Norris et al., "Controlling ground and excited state properties through ligand changes in ruthenium polypyridyl complexes," Inorganic Chemistry, vol. 53, no. 11, pp. 5637-5646, 2014.

[43] S. Campagna, F. Puntoriero, F. Nastasi, G. Bergamini, and V. Balzani, "Photochemistry and photophysics of coordination compounds: ruthenium," in Photochemistry and Photophysics of Coordination Compounds I,Topics in Current Chemistry, pp. 117-214, Springer, Berlin, Germany, 2007.

[44] W. F. Wacholtz, R. A. Auerbach, and R. H. Schmehl, "Independent control of charge-transfer and metal-centered excited states in mixed-ligand polypyridine ruthenium(II) complexes via specific ligand design," Inorganic Chemistry, vol. 25, no. 2, pp. 227-234, 1986.

[45] A. Juris, V. Balzani, F. Barigelletti, S. Campagna, P. Belser, and A. von Zelewsky, "Ru(II) polypyridine complexes: photophysics, photochemistry, eletrochemistry, and chemiluminescence," Coordination Chemistry Reviews, vol. 84, pp. 85-277, 1988.

[46] I. Veroni, A. Rontoyianni, and C. A. Mitsopoulou, "Synthesis and characterization of a novel complex: $\mathrm{Mo}(\mathrm{CO}) 4[2-$ (2'pyridyl)quinoxaline]. An insight based on experimental and theoretical data," Dalton Transactions, vol. 2, pp. 255-260, 2003.

[47] I. Veroni, C. A. Mitsopoulou, and F. J. Lahoz, "Synthesis, spectroscopic properties and crystal structure of mononuclear tricarbonylrhenium(I) chloride complexes carrying 6-functionalised quinoxalines," Journal of Organometallic Chemistry, vol. 693, no. 14, pp. 2451-2457, 2008.

[48] C. Kefalidi, E. Koutsouri, L. Marchiò, A. Zarkadoulas, S. Efstathiadou, and C. A. Mitsopoulou, "Synthesis, characterization and crystal structure of rhenium(I) tricarbonyl diimine complexes coupled with their efficiency in producing hydrogen in a photocatalytic system," Polyhedron, vol. 110, pp. 157-164, 2016.

[49] C. Makedonas, I. Veroni, and C. A. Mitsopoulou, "Pentacarbonyl[2-( $2^{\prime}$-pyridyl)quinoxaline- $\left.\kappa \mathrm{N} 4\right]$ tungsten: a combined study of its conformational and electronic structure based on experimental and DFT-TDDFT data," European Journal of Inorganic Chemistry, vol. 2007, no. 1, pp. 120-131, 2007.

[50] I. Veroni, C. A. Mitsopoulou, and F. J. Lahoz, "Isolation, X-ray structure and properties of an unusual pentacarbonyl $\left(2,2^{\prime}\right.$ pyridyl-quinoxaline) tungsten complex," Journal of Organometallic Chemistry, vol. 691, pp. 5967-5975, 2006.

[51] K. Ypsilantis, T. Tsolis, A. Kourtellaris, M. J. Manos, J. C. Plakatouras, and A. Garoufis, "Synthesis, reactivity and characterization of $\mathrm{Pt}(\mathrm{ii})$ complexes with $\mathrm{N}, \mathrm{N}^{\prime}$ chelating ligands; structure and dimethylsulfoxide reactivity relationship," Dalton Transactions, vol. 46, no. 5, pp. 1467-1480, 2017.
[52] W.-Y. Bi, W.-L. Chai, X.-Q. Lu, J.-R. Song, and F. Bao, "Syntheses and supramolecular structures of silver(I) complexes based on 2-(2'-pyridyl)-quinoxaline," Journal of Coordination Chemistry, vol. 62, no. 12, pp. 1928-1938, 2009.

[53] D.-L. Ma, C.-M. Che, F.-M. Siu, M. Yang, and K.-Y. Wong, "DNA binding and cytotoxicity of ruthenium(II) and rhenium(I) complexes of 2-Amino-4-phenylamino-6-(2-pyridyl)-1,3,5-triazine," Inorganic Chemistry, vol. 46, no. 3, pp. 740-749, 2007.

[54] N. C. Garbett, P. A. Ragazzon, and J. B. Chaires, "Circular dichroism to determine binding mode and affinity of ligandDNA interactions," Nature Protocols, vol. 2, no. 12, pp. 3166-3172, 2007.

[55] S. S. Jain, M. Polak, and N. V. Hud, "Controlling nucleic acid secondary structure by intercalation: effects of DNA strand length on coralyne-driven duplex disproportionation," Nucleic Acids Research, vol. 31, no. 15, pp. 4608-4615, 2003.

[56] A.-G. Zhang, Y.-Z. Zhang, Z.-M. Duan et al., "Dual molecular light switches for $\mathrm{pH}$ and DNA based on a novel $\mathrm{Ru}(\mathrm{II})$ complex. A non-intercalating $\mathrm{Ru}(\mathrm{II})$ complex for DNA molecular light switch," Inorganic Chemistry, vol. 50, no. 14, pp. 6425-6436, 2011.

[57] C. Tan, J. Liu, L. Chen, S. Shi, and L. Ji, "Synthesis, structural characteristics, DNA binding properties and cytotoxicity studies of a series of Ru(III) complexes," Journal of Inorganic Biochemistry, vol. 102, no. 8, pp. 1644-1653, 2008.

[58] H.-J. Yin, A.-G. Zhang, L.-H. Gao, H. Zhao, and K.-Z. Wang, "DNA groove-binding and acid-base properties of a $\mathrm{Ru}(\mathrm{II})$ complex containing anthryl moieties," Nucleosides, Nucleotides \& Nucleic Acids, vol. 39, no. 4, pp. 592-614, 2020.

[59] E. Lioli, V. Psycharis, C. P. Raptopoulou, E. K. Efthimiadou, and C. A. Mitsopoulou, "Synthesis, characterization, DNA binding and cytotoxicity studies of two novel $\mathrm{Cu}(\mathrm{II})-2-\left(2^{\prime}\right.$ pyridyl) quinoxaline complexes," Journal of Inorganic Biochemistry, vol. 208, Article ID 111077, 2020.

[60] M.-J. Han, Z.-M. Duan, Q. Hao, S.-Z. Zheng, and K.-Z. Wang, "Molecular light switches for Calf thymus DNA based on three $\mathrm{Ru}(\mathrm{II})$ bipyridyl complexes with variations of heteroatoms," The Journal of Physical Chemistry C, vol. 111, no. 44, pp. 16577-16585, 2007.

[61] F. M. O’Reill and J. M. Kelly, "Photophysical study of DNAbound complexes containing two covalently linked $\left[\mathrm{Ru}\left(2,2^{\circ}\right.\right.$ bipyridine)3]2+-like centers," The Journal of Physical Chemistry B, vol. 104, pp. 7206-7213, 2000.

[62] A. E. Friedman, J. C. Chambron, J. P. Sauvage, N. J. Turro, and J. K. Barton, "A molecular light switch for DNA: Ru(bpy) 2(dppz)2+," Journal of the American Chemical Society, vol. 112, no. 12, pp. 4960-4962, 1990.

[63] C. Hiort, P. Lincoln, and B. Nordén, "DNA binding of .DELTA.- and .LAMBDA.-[Ru(phen)2DPPZ]2+," Journal of the American Chemical Society, vol. 115, no. 9, pp. 3448-3454, 1993.

[64] N. C. Garbett, N. B. Hammond, and D. E. Graves, "Influence of the amino substituents in the interaction of ethidium bromide with DNA," Biophysical Journal, vol. 87, no. 6, pp. 3974-3981, 2004.

[65] J. R. Lakowicz and G. Weber, "Quenching of fluorescence by oxygen. Probe for structural fluctuations in macromolecules," Biochemistry, vol. 12, no. 21, pp. 4161-4170, 1973.

[66] C. Qiao, S. Bi, Y. Sun, D. Song, H. Zhang, and W. Zhou, "Study of interactions of anthraquinones with DNA using ethidium bromide as a fluorescence probe," Spectrochimica Acta Part A: Molecular and Biomolecular Spectroscopy, vol. 70, no. 1, pp. 136-143, 2008. 
[67] A. Ambroise and B. G. Maiya, "Ruthenium(II) complexes of 6,7-dicyanodipyridoquinoxaline: synthesis, luminescence studies, and DNA interaction," Inorganic Chemistry, vol. 39, no. 19 , pp. 4264-4272, 2000.

[68] F. A. Beckford, J. Thessing, M. Shaloski et al., "Synthesis and characterization of mixed-ligand diimine-piperonal thiosemicarbazone complexes of ruthenium(II): biophysical investigations and biological evaluation as anticancer and antibacterial agents," Journal of Molecular Structure, vol. 992, no. 1-3, pp. 39-47, 2011.

[69] B. Selvakumar, V. Rajendiran, P. Uma Maheswari, H. Stoeckli-Evans, and M. Palaniandavar, "Structures, spectra, and DNA-binding properties of mixed ligand copper(II) complexes of iminodiacetic acid: the novel role of diimine coligands on DNA conformation and hydrolytic and oxidative double strand DNA cleavage," Journal of Inorganic Biochemistry, vol. 100, no. 3, pp. 316-330, 2006.

[70] C. Sánchez-Cano and M. J. Hannon, "Cytotoxicity, cellular localisation and biomolecular interaction of non-covalent metallo-intercalators with appended sex hormone steroid vectors," Dalton Transactions, vol. 48, pp. 10765-10773, 2009.

[71] J. Chen, J. Wang, Y. Deng et al., "Ru (II) complexes bearing O, O-chelated ligands induced apoptosis in A549 cells through the mitochondrial apoptotic pathway," Bioinorganic Chemistry and Applications, vol. 2020, Article ID 8890950, 16 pages, 2020.

[72] J. Chen, J. Wang, Y. Deng et al., "Novel cyclometalated Ru(II) complexes containing isoquinoline ligands: synthesis, characterization, cellular uptake and in vitro cytotoxicity," European Journal of Medicinal Chemistry, vol. 203, Article ID 112562,2020

[73] M. He, F. Du, W.-Y. Zhang et al., "Photoinduced anticancer effect evaluation of ruthenium(II) polypyridyl complexes toward human lung cancer A549 cells," Polyhedron, vol. 165, pp. 97-110, 2019.

[74] D. Das and P. Mondal, "Interaction of ruthenium(ii) antitumor complexes with d(ATATAT)2 and d(GCGCGC)2: a theoretical study," New Journal of Chemistry, vol. 39, no. 4, pp. 2515-2522, 2015.

[75] M. Ganeshpandian, M. Palaniandavar, A. Muruganantham, S. K. Ghosh, A. Riyasdeen, and M. A. Akbarsha, "Ruthenium(II)-arene complexes of diimines: effect of diimine intercalation and hydrophobicity on DNA and protein binding and cytotoxicity," Applied Organometallic Chemistry, vol. 32, no. 3, Article ID e4154, 2018.

[76] S. Satyanarayana, J. C. Dabrowiak, and J. B. Chaires, "Neither .DELTA.- nor .LAMBDA.-tris(phenanthroline)ruthenium(II) binds to DNA by classical intercalation," Biochemistry, vol. 31, no. 39, pp. 9319-9324, 1992. 